\title{
Variability in upwelling intensity and nutrient regime in the coastal upwelling system offshore Namibia: results from sediment archives
}

\author{
Kay-Christian Emeis · Ulrich Struck • \\ Thomas Leipe · Timothy G. Ferdelman
}

Received: 12 September 2005/ Accepted: 2 March 2007/Published online: 23 August 2007

(C) Springer-Verlag 2007

\begin{abstract}
The coastal upwelling system offshore Namibia is ideally suited to address a focal question of the Integrated Marine Biogeochemistry and Ecosystem Research Programme: what are the mechanisms that drive long-term changes in ecosystems? Considerable interannual variability in climatic forcing is indicated by long time series of meteorological and remote sensing observation; these accompany considerable interannual to interdecadal changes in the upwelling intensity over the last 100 years, as well as a centennial trend. On longer time scales, the only archives available are sediment records spanning the late Holocene. To decipher the sediment record, we mapped surface-sediment patterns of proxies for physical (sea surface temperature/SST from alkenone unsaturation indexes) and nutrient ( $\delta^{15} \mathrm{~N}$ on bulk sedimentary $\mathrm{N}$ ) variables. Their present-day surface-sediment patterns outline the coastal upwelling cells and filaments and associated high productivity area. Analysed in an array of dated sediment cores, the spatial patterns of SST suggest long-term ( $>100$ years) variability in the location and intensity of individual
\end{abstract}

\section{K.-C. Emeis ( $\square)$}

IfBM Universität Hamburg,

Bundesstr. 55, 20146 Hamburg, Germany

e-mail: emeis@geowiss.uni-hamburg.de

\section{U. Struck}

Museum für Naturkunde der Humboldt Universität zu Berlin, Invalidenstraße 43, 10115 Berlin, Germany

\section{T. Leipe}

Institute For Baltic Sea Research,

Seestrasse 15, 18119 Warnemünde, Germany

T. G. Ferdelman

MPI for Marine Microbiology,

Celsiusstrasse 1, 28359 Bremen, Germany upwelling cells. The patterns of $\delta^{15} \mathrm{~N}$ outline an area of intense denitrification near the coast, and advection of water with low-oxygen concentrations in the undercurrent from the North. $\delta^{15} \mathrm{~N}$ exhibits considerable downcore variability, in particular over the last 50 years. The variability appears to be governed by differences in extent of denitrification and thus of the shelf oxygen balance, which appears to have deteriorated in the last 50 years. Together, the data suggest that SST and denitrification conditions have remained in the narrow bounds outlined by today's patterns in surface sediments, but that spatially small variability in upwelling intensity and make-up of upwelling feed waters induced considerable changes in the lower trophic levels of the coastal upwelling ecosystem over the last 6,000 years. Attempts to correlate proxy records from sediments with observational time series and regional climate reconstructions were not successful, possibly because annual to interannual environmental signals are erased in the process of sediment formation.

\section{Introduction}

Coastal upwelling systems are known to be both active (as sources/sinks for $\mathrm{CO}_{2}$ and nutrients) and passive (as sounding boards of changes in external forcing) components of global and regional climate change (Summerhayes et al. 1992, 1995a). Their importance stems from several factors.

First, their role in the global marine carbon cycle in terms of mass fluxes by far outweighs their modest regional extent. They are areas of substantial $\mathrm{CO}_{2}$ degassing, and at the same time they are focal points for nutrient delivery from the subthermocline of the adjacent oceans to the 
euphotic zone and thus support an immensely powerful biological pump in the near and far field around the areas of physical upwelling (Berger et al. 1989; Diffenbaugh et al. 2004; Watson 1995).

Second, strong and direct links exist between physical forcing (e.g. intensity of trade wind forcing or changes in wind stress curl) and response in the physical system of coastal upwelling (f.e., intensity and spatial extent of upwelling, location of filaments) on the one hand, and possible influences on the chemical and biological upwelling systems on the other hand. Examples of such responses to outside forcing include changes in oxygen levels and spatial extent of suboxia/anoxia; carbon dioxide versus methane degassing; changes in organic carbon sequestration and burial; changes in the amounts and ratios of nutrients exported from the shelf upwelling system out to the adjacent pelagic ocean. In terms of consequences for higher ecosystem levels, change in the physical forcing is a prime suspect for changes in the biological structure, functioning and diversity of entire ecosystems. Case in point are global and regional "regime shifts" seen in the geographical predominance and biomass of small pelagic fish in coastal other upwelling systems (Chavez et al. 2003; Schwartzlose et al. 1999).

Third, coastal upwelling areas offer sedimentary archives of high-temporal resolution that may overcome the problem of limited observation periods. Observing and evaluating ecosystem changes and their root causes while the system is in transition from one state to the next is difficult, and long-term changes require observational records of matching long durations. Such records are usually lacking for coastal upwelling areas; those few time series that exist are usually incomplete and limited to several decades at most. When looking for evidence of recurrent changes in upwelling systems extending from the interannual to millennial time scale, or for stochastic events preceding observation periods, we have to rely on proxy records: proxy records are time series of some variable that can be observed/measured and which has a known and statistically significant relationship to another, unobservable environmental variable of interest. The task of reconstructing ecosystem variability in coastal upwelling systems before observations began thus entails an identification and definition of suitable proxies.

These properties of and mechanisms in coastal upwelling systems mark them as prime candidates for studies under the auspices of Integrated Marine Biogeochemistry and Ecosystem Research, the IMBER initiative. It aims to understand, how biogeochemical cycles and ecosystems in the ocean react to global change, and how those reactions may in turn act on global change. In the present paper we present data and discuss the evidence for changes in the environment of the coastal upwelling system offshore
Namibia, the northern sector of the large Benguela upwelling system. The data raised and presented here are restricted to the shelf offshore Nambibia between 19 and $25^{\circ} \mathrm{S}$. The processes captured in the sediment records entail the coastal upwelling system only and span the time since the modern coastal upwelling system was established in the mid-Holocene (around 6,000 years ago), when post-glacial sea level rise had slowed and the modern shelf circulation patterns had been established.

\section{The setting}

Atmospheric and oceanic circulation

The coastal upwelling region offshore Angola, Namibia and South Africa is a classical example for an eastern boundary current system. It is driven by winds around the high air pressure cell that forms the South Atlantic Anticyclone (SAA) with a core position at about $30^{\circ} \mathrm{S}, 10^{\circ} \mathrm{W}$ (Schell 1968). Together with the equatorial low-pressure belt and highly variable continental low pressure cells over southern Africa (such as the Angola Low and Kalahari Low), these atmospheric centres of action control strength and direction of the Southeast Trades (SET) along southwest African coasts and thus the wind stress curl. The SET provides the driving force for the Benguela Current (BC) which feeds water masses into the South Equatorial Current (SEC) as part of the basin-scale wind-driven oceanic circulation (Fig. 1).

A comprehensive review of the circulation in the SE Atlantic Ocean and the Benguela System is given in Shannon and Nelson (1996). The northward component of the SET is responsible for offshore transport of water in near-surface layers. The resulting pressure deficit over the shelf is partly compensated by onshore transport of Eastern South Atlantic Central Water (ESACW) from $\sim 200 \mathrm{~m}$ depth. ESACW originates in the source region of the BC near the Cape of Good Hope and is transported northwards along the upper continental slope at water depths of $<400 \mathrm{~m}$. Water of deeper layers frequently carries the signature of Antarctic Intermediate Water (AIW) from up to $500 \mathrm{~m}$ water depth (Lutjeharms and Valentine 1987; Stramma and Peterson 1989). The overall coastal upwelling area is about $150-200 \mathrm{~km}$ wide and is composed of several locally fixed upwelling cells-determined by coastal morphology and topography (Lutjeharms and Meeuwis 1987)—extending up to $600 \mathrm{~km}$ offshore where upwelling filaments interlace with open ocean water (Lutjeharms and Stockton 1987). The northern boundary of coastal upwelling is given by the Angola-Benguela-Frontal Zone (ABFZ) between 15 and $17^{\circ} \mathrm{S}$ (Boyd et al. 1987; Lass et al. 2000). Its location is variable in space and in time and 


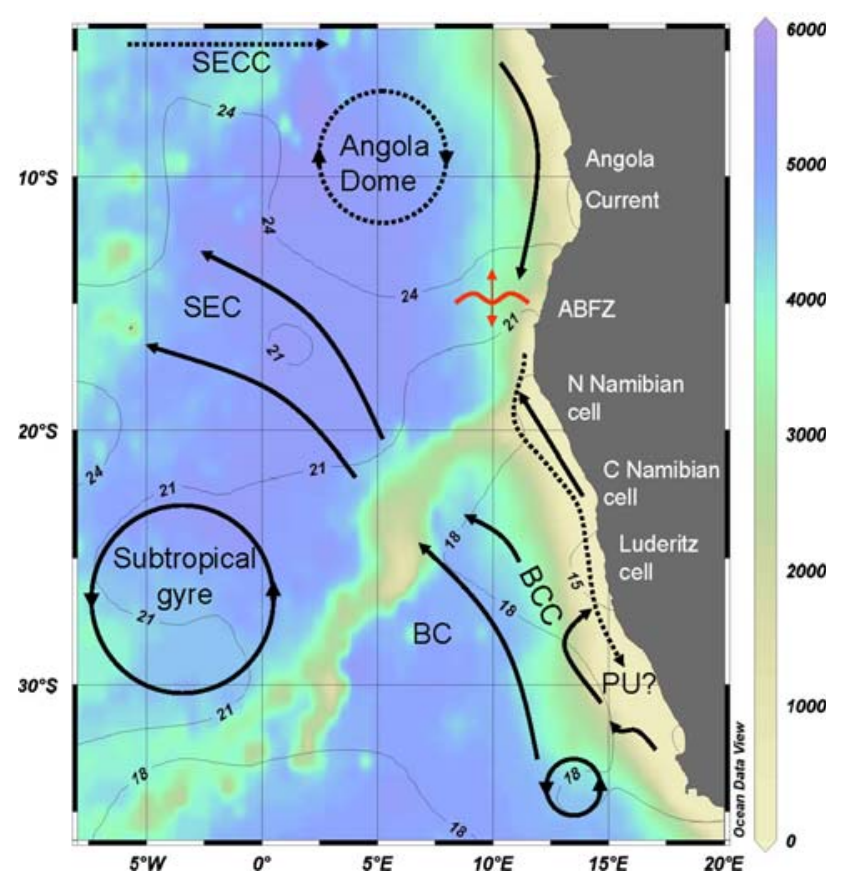

Fig. 1 Bathymetry of the South East Atlantic overlain with climatological sea surface temperatures (contour lines, in ${ }^{\circ} \mathrm{C}$ ) (Gouretski and Koltermann 2004). Arrows show surface (solid) and subsurface (dashed) hydrographic features (Hardman-Mountford et al. 2003). $S E C$ south equatorial current, $S E C C$ south equatorial counter current, $B C$ benguela oceanic current, $B C C$ benguela coastal current, $A B F Z$ Angola-Benguela front, $P U$ poleward undercurrent

mainly depends on the constellation of air pressure gradients between the Intertropical Convergence Zone (ITCZ) and the SAA (Meeuwis and Lutjeharms 1990; Shannon et al. 1987).

The southern boundary of the Benguela upwelling regime coincides with the retroflection zone of the Agulhas Current. In coastal zones south of $\sim 33^{\circ} \mathrm{S}$, relatively warm surface water originates from the Indian Ocean and its equatorward spreading forms a highly variable frontal zone which separates cold upwelling water in the North from relative warm water in the South (Shannon and Nelson 1996). The Benguela upwelling regime thus is the only Eastern Boundary Current system with a poleward border of warm water.

\section{Hydrography and oxygen balance}

The chain of cause and effect from physical forcing to chemical environment and ecosystem response hinges on the oxygen supply and consumption (and linked to it, the nutrient balance) as the master variable.

Three hydrographic features are important with respect to the oxygen supply for shelf waters offshore Namibia: (a) A poleward undercurrent compensates the effect of northward Ekman transports which depend on the strength of the equatorward component of the SET (Lass et al. 2000). This poleward undercurrent of South Atlantic Central Water (SACW) originates in the Gulf of Guinea and entrains 'old' and oxygen-depleted waters of the Angola Dome (Chapman and Shannon 1987). The mixed water mass arrives at the northernmost Namibian offshore zones with oxygen concentrations well below $90 \mu \mathrm{mol} / \mathrm{L}$ and hugs the shelf break as a focused jet. (b) ESACW is advected onshore (O'Toole 1980) as an intermediate crossshore compensation current that balances the Ekman offshore transport in near-surface layers. The resulting mixed water typically has oxygen concentrations of $178 \mu \mathrm{mol} / \mathrm{L}$. (c) A third water mass which has considerable effects on the hydrography, biogeochemistry and ecosystem states on the shelf offshore Namibia is warm tropical surface water normally found north of the ABFZ as described for case (a). Under specific conditions (during Benguela Niños, see below) it is advected southward along the coast to the area off Walvis Bay (and sometimes even further south).

Changes of SET strength and location disrupt the oxygen balance over the shelf via weakened upwelling and source water makeup. The cross-shelf compensation current of ESACW reacts instantaneously to changing tradewind intensity and is immediately interrupted when the trade winds stop. In other words, the most important oxygen source for waters overlying the shelf is directly coupled to fluctuations in the coast-parallel component of the wind field on the time-scale of hours and/ or few days (Fennel 1999). Only the poleward undercurrent, which has a longer response time of weeks to months, remains to counteract oxygen consumption in the water column and the sediment. However, water in the undercurrent is already depleted in oxygen. In addition, oxygen demand is enhanced during slackening of the SET, because stabilisation of the water column promotes plankton blooms over the shelf (Bailey 1991). Oxygen levels of near sea-bed layers over the shelf can only increase after the trade winds resume, again turning on the cross-shelf "conveyor" of oxygen.

Chemical and biological characteristics of coastal upwelling

The feed waters of coastal upwelling on the Namibian Shelf have characteristic nutrient and oxygen concentrations, which are determined by processes that steer the relative proportions of the individual feed waters. Aside from this, nutrient and oxygen regimes are also influenced by internal sources and sinks: by oxygen consumption, by gains of nutrients from sediments (Bailey 1991) or-in the case of nitrate-by losses to suboxic and anoxic processes 
Table 1 Location of cores studied and parameters measured

\begin{tabular}{|c|c|c|c|c|c|c|}
\hline Expedition/station number & Latitude & Longitude & Water depth & Dating & $\delta^{15} \mathrm{~N}$ & SST \\
\hline \multicolumn{7}{|l|}{ R/V Meteor 48-2, 2000} \\
\hline 226620 & $22^{\circ} 45.51^{\prime} \mathrm{S}$ & $14^{\circ} 18.87^{\prime} \mathrm{E}$ & $83 \mathrm{~m}$ & $\mathrm{x}$ & $\mathrm{x}$ & $\mathrm{x}$ \\
\hline \multicolumn{7}{|c|}{ Gravity core SL226620 taken at same location } \\
\hline 226680 & $23^{\circ} 46.52^{\prime} \mathrm{S}$ & $14^{\circ} 17.96^{\prime} \mathrm{E}$ & $109 \mathrm{~m}$ & $\mathrm{x}$ & $\mathrm{x}$ & $\mathrm{x}$ \\
\hline 226720 & $22^{\circ} 09.98^{\prime} \mathrm{S}$ & $14^{\circ} 04.07^{\prime} \mathrm{E}$ & $69 \mathrm{~m}$ & $\mathrm{x}$ & $\mathrm{x}$ & $\mathrm{x}$ \\
\hline 226770 & $21^{\circ} 22.97^{\prime} \mathrm{S}$ & $13^{\circ} 40.00^{\prime} \mathrm{E}$ & $51 \mathrm{~m}$ & $\mathrm{x}$ & $\mathrm{x}$ & $\mathrm{x}$ \\
\hline 226790 & $19^{\circ} 47.00^{\prime} \mathrm{S}$ & $12^{\circ} 51.61^{\prime} \mathrm{E}$ & $50 \mathrm{~m}$ & $\mathrm{x}$ & $\mathrm{x}$ & $\mathrm{x}$ \\
\hline 226870 & $22^{\circ} 40.03^{\prime} \mathrm{S}$ & $14^{\circ} 00.03^{\prime} \mathrm{E}$ & $125 \mathrm{~m}$ & $\mathrm{x}$ & $\mathrm{x}$ & $\mathrm{x}$ \\
\hline \multicolumn{7}{|l|}{ R/V A. v. Humboldt, 2004} \\
\hline 266030 & $24^{\circ} 55.05^{\prime} \mathrm{S}$ & $14^{\circ} 25.23^{\prime} \mathrm{E}$ & $120 \mathrm{~m}$ & & & $\mathrm{x}$ \\
\hline 265830 & $24^{\circ} 59.95^{\prime} \mathrm{S}$ & $14^{\circ} 35.03^{\prime} \mathrm{E}$ & $96 \mathrm{~m}$ & & & $\mathrm{x}$ \\
\hline \multicolumn{7}{|l|}{ R/V P. Kottsov, 1997} \\
\hline NAM-1 (kasten core) & $22^{\circ} 40.10^{\prime} \mathrm{S}$ & $14^{\circ} 00.10^{\prime} \mathrm{E}$ & $125 \mathrm{~m}$ & $\mathrm{x}$ & $\mathrm{x}$ & $\mathrm{x}$ \\
\hline GeoB 4502 & $23^{\circ} 08.10^{\prime} \mathrm{S}$ & $13^{\circ} 10.06^{\prime} \mathrm{E}$ & $370 \mathrm{~m}$ & & $\mathrm{x}$ & $\mathrm{x}$ \\
\hline
\end{tabular}

Gravity core SL 226620 was taken at station 226620 biological productivity (both pelagic and benthic), terrigenous input, and diagenesis (Bremner 1983). Sediments of the mud belt archived the conditions in and variability of coastal upwelling over the last 3,000-6,000 years in hightemporal resolution, with sedimentation rates on the order of $100 \mathrm{~cm}$ per 1,000 years (Struck et al. 2002). They are our only means to reconstruct conditions in the upwelling system before scientific measurements began. The mud thickness and local mud accumulation rate-and thus the temporal resultion achieved by paleoceanographic reconstructions-is determined by the morphology of the basement that was transgressed by the sea in the course of the Holocene. That morphology had small-scale variability due to incision of valleys during glacial sea level lowstand (Vogt 2002) which are now filled with diatomaceous mud.

Results from 60 surface sediment samples, 9 short multicores and 1 long gravity core will be presented here that have been analysed from the shelf and upper slope between 15 and $25^{\circ} \mathrm{S}$. Surface sediment samples serve to examine the present-day patterns of sediment properties, and how they relate to modern conditions in the water column. Several short $(<50 \mathrm{~cm})$ multicores from different sectors of the mud belt have been analysed and dated by the $210-\mathrm{Pb}$ method, yielding time series of data along the entire coast from 26 to $20^{\circ} \mathrm{S}$ for the last 150 years (Table 1). Assuming that sedimentation rates can approximately be extrapolated from the thickness of the Holocene mud and the age of a conspicuous sediment layer at its base, these multicores extend back several hundreds of years. Finally, a long $(435 \mathrm{~cm})$ sediment core SL226620 has been dated by AMS-14C and has been analysed (Table 2).

Below we present three types of proxy data representative of physical, chemical and higher ecosystem variability, respectively. We proceed from the patterns in 
Table 2 Results of AMS- ${ }^{14} \mathrm{C}$ dating on $\sim 2,000$ specimens of planktonic foraminifer tests per sample in gravity core SL 226620 and the associated multicore $(M U C)\left(22^{\circ} 45.51^{\prime} \mathrm{S}, 14^{\circ} 18.87^{\prime} \mathrm{E}, 81 \mathrm{~m}\right.$ water depth)

\begin{tabular}{|c|c|c|c|c|c|c|c|c|c|}
\hline Lab ID & Sample depth top (cm) & Sample depth bottom $(\mathrm{cm})$ & $\mathrm{mgC}$ & ${ }^{14} \mathrm{C}$ age & $\pm 1 \sigma$ & DR & Calendar year & $\delta^{13} \mathrm{C}$ & $\pm 1 \sigma$ \\
\hline KIA 21408 & MUC 45 & MUC 48 & 1.1 & 1,315 & 25 & 400 & 485 & -0.39 & -0.39 \\
\hline KIA 18203 & 125 & 175 & 1.1 & 3,430 & 30 & 400 & 2,925 & 2.23 & 0.13 \\
\hline KIA 18204 & 164 & 214 & 1.5 & 3,785 & 25 & 400 & 3,310 & 0.83 & 0.11 \\
\hline KIA 18205 & 205.5 & 255 & 1 & 4,135 & 25 & 400 & 3,810 & 2.11 & 0.14 \\
\hline KIA 21409 & 311 & 361 & 0.8 & 4,785 & 35 & 400 & 4,635 & -3.94 & 0.09 \\
\hline
\end{tabular}

Dating was done at the Leibniz dating facility, Kiel, FRG. Conversion of raw ${ }^{14} \mathrm{C}$ ages to calendar years is based on the IntCal Marine04 calibration curve

surface sediments to core records, examining developments of different time scales.

\section{Methods}

Sea surface temperature proxy: alkenone unsaturation ratios

Amongst the proxies, sea surface temperature stands out as the master variable that can be used to identify changes in upwelling intensity and/or spatial variability through time. Changes in sea surface temperatures can be detected by alkenone unsaturation ratios. These lipids are biomarkers of marine haptophytes, namely Emiliania huxleyi, and record the ambient sea surface temperature during growth of the algae. The degree of unsaturation is expressed as the ratio between di- and tri-unsaturated ketones with 37 carbon atoms (Brassell et al. 1986; Prahl and Wakeham 1987):

$U_{37}^{k^{\prime}}=\left(C_{37: 2}\right) /\left(C_{37: 2}+C_{37: 3}\right)$.

The index has been found to co-vary linearly with SST (Müller et al. 1998). This proxy is insensitive to diagenesis and variable oxygen conditions. The methods used to generate the data presented here are described in Blanz et al. (2005). The analytical error estimated for the method is $<0.4^{\circ} \mathrm{C}$ in repeated determinations of individual samples; the calibration error has been estimated at $1^{\circ} \mathrm{C}$.

A possible problem with the reconstruction of SST based on the alkenone unsaturation index is a bias introduced by mixing older alkenone-bearing materials into the sediment (Mollenhauer et al. 2003). This has been shown to severely affect the ages of alkenones on the adjacent continental slope offshore Namibia, there compromising the synchroneity of SST in sediments and in surface waters. However, an age discrepancy was not noted in surface sediments from the shelf mud lens (G. Mollenhauer, personal communication, 2005). SST reconstructed from alkenone unsaturation ratios thus should provide a good index of changes in the intensity of upwelling. When analysed in a series of cores spread out over the length of the coastal upwelling system, it should in addition reveal possible latitudinal shifts of individual upwelling cells.

Nutrient abundance/denitrification proxy: nitrogen isotopic composition

The second proxy traces changes in factors that result in differential fractionation of nitrogen stable isotopes $\left({ }^{15} \mathrm{~N}\right.$ and ${ }^{14} \mathrm{~N}$ ) in the course of chemical or biological processes. Nitrogen is a key element in regulating biological processes in the ocean. The ratio of the two stable $\mathrm{N}$-isotopes in sinking particles and surface sediments reflects N-sources, biogeochemical processes, and nutrient regime in the overlying water. The ratio is expressed as $\delta^{15} \mathrm{~N}$ after determining the abundance of the two isotopes in samples (after combustion and reduction of $\mathrm{NOx}$ to $\mathrm{N}_{2}$ ) by mass spectrometry:

$\delta^{15} \mathrm{~N}=\frac{R_{\text {sample }}-R_{\text {standard }}}{R_{\text {standard }}} \times 1,000[\%]$, with $R=\frac{15 \mathrm{~N}}{{ }^{14} \mathrm{~N}}$

$\mathrm{N}_{2}$ in air-a commonly used standard-has a $\delta^{15} \mathrm{~N}$ of $0 \%$. The method used to generate the data presented here is given in Voß et al. (2005).

The ratio is often used as a proxy to reconstruct marine nutrient cycles in the geological past, and in particular the extent of nitrate assimilation/utilisation (Altabet and Francois 1994). Because we deal with an ocean margin setting on small spatial scales, and because the proximal upwelling area is never nitrate depleted, we consider this influence as secondary to the influence of variable denitrification intensity. Denitrification in the water columnbut not in sediment-preferentially removes ${ }^{14} \mathrm{~N}$ to $\mathrm{N}_{2}$ and results in enriched $\delta^{15} \mathrm{~N}$ in organic matter produced (Lehmann et al. 2005). There is to our knowledge no data on $\mathrm{N}$-isotope fractionation associated with the anaerobic 
ammonia oxidation (anammox), which is a quantitatively important process of nitrate removal in suboxic and anoxic water in the area (Kuypers et al. 2005). We thus do not separate denitrification from anammox in the context of this paper and just state that both are tied to oxygen deficient waters. A possible bias on the use of ${ }^{15} \mathrm{~N} /{ }^{14} \mathrm{~N}$ ratios as a proxy for denitrification intensity is the differential degradation of proteinaceous biological products under oxic and anoxic conditions (Gaye-Haake et al. 2005; Lehmann et al. 2002). Several studies suggested that the $\delta^{15} \mathrm{~N}$ ratio of material deposited under suboxic to anoxic conditions is lower than that of material deposited under oxic conditions. Also, there appears to be an effect of sedimentation rates, with better preservation of original ratios in rapidly accumulating sediments due to better sealing efficiency. Low $\delta^{15} \mathrm{~N}$ from enhanced preservation may thus be associated with the antagonistic process of ${ }^{15} \mathrm{~N}$ enrichment by denitrification.

\section{Estimates of mass accumulation using ${ }^{210} \mathrm{~Pb}$}

Sediment accumulation rates $(\omega)$ were calculated from the down-core changes of ${ }^{210} \mathrm{~Pb}$ excess activity. To account for differences in sediment porosity and consolidation, excess ${ }^{210} \mathrm{~Pb}$ was plotted versus cumulative sediment dry weight. Sedimentation rates $(r)$ were derived from the slope $(S)$ of linear regression in those parts of the sediments that appeared to be unaffected by mixing (Carpenter et al. 1982):

$r=\frac{\lambda}{S}$ with $\lambda=\frac{\ln 2}{t_{1 / 2}}$

Herein, $\lambda$ is the decay coefficient of ${ }^{210} \mathrm{~Pb}$; half-life $\left(t_{1 / 2}\right)$ of ${ }^{210} \mathrm{~Pb}$ is 22.3 years. For each depth an age was calculated from cumulative dry weight and $r\left(\mathrm{~g} / \mathrm{cm}^{2} /\right.$ year). Then, $\omega$ (cm/year) were calculated from age and depth of the individual samples.

The calculation of sedimentation rates is based on the assumption that ${ }^{210} \mathrm{~Pb}_{\mathrm{xs}}$ flux and sedimentation were constant over time. However, it should be noted, that $\omega$ calculated from profiles of ${ }^{210} \mathrm{~Pb}_{\mathrm{xs}}$ often overestimate the actual accumulation rates, as gradually decreasing mixing efficiency with sediment depth might result in a depth profile indicating exponential decay, which is falsely interpreted as undisturbed sediment accumulation (e.g. Nittrouer et al. 1984). In all, six multicores have been dated and Fig. 2 shows one example (MUC 226680) of a profile with depth of excess $210-\mathrm{Pb}$ from the mud lens. All cores showed zones of mixing extending 10-15 cm into the surface layers, which cause uncertainties in the age models.

\section{Results and discussion}

Present-day patterns and past variability from the sediment record

\section{SST}

Patterns of $\mathrm{UK}^{\prime} 37$ in surface sediments and the corresponding SST estimates agree with observed ranges (12$>20^{\circ} \mathrm{C}$ ) and image the general patterns of temperatures observed at the sea surface (Fig. 3a, b). Coldest SST estimates mark nearshore upwelling between 22 and $26^{\circ} \mathrm{S}$. This is north of the prominent Lüderitz upwelling cell that in observations has the lowest SST. Unfortunately, our efforts to sample the sea floor in this upwelling cell did not yield any recent sediment, but only hard grounds. A second minimum of SST derived from alkenones is seen in the vicinity of Walvis Bay (Fig. 3b), corresponding to the central Namibian upwelling cell. The minimum temperatures found in sediments at these two locations are between 12 and $13^{\circ} \mathrm{C}$, corresponding to the range of freshly upwelled water (Hagen et al. 2001). The depressed SST estimates indicative of the coastal upwelling have an offshore extension of several hundred kilometers, similar to what is seen in the SST climatology.

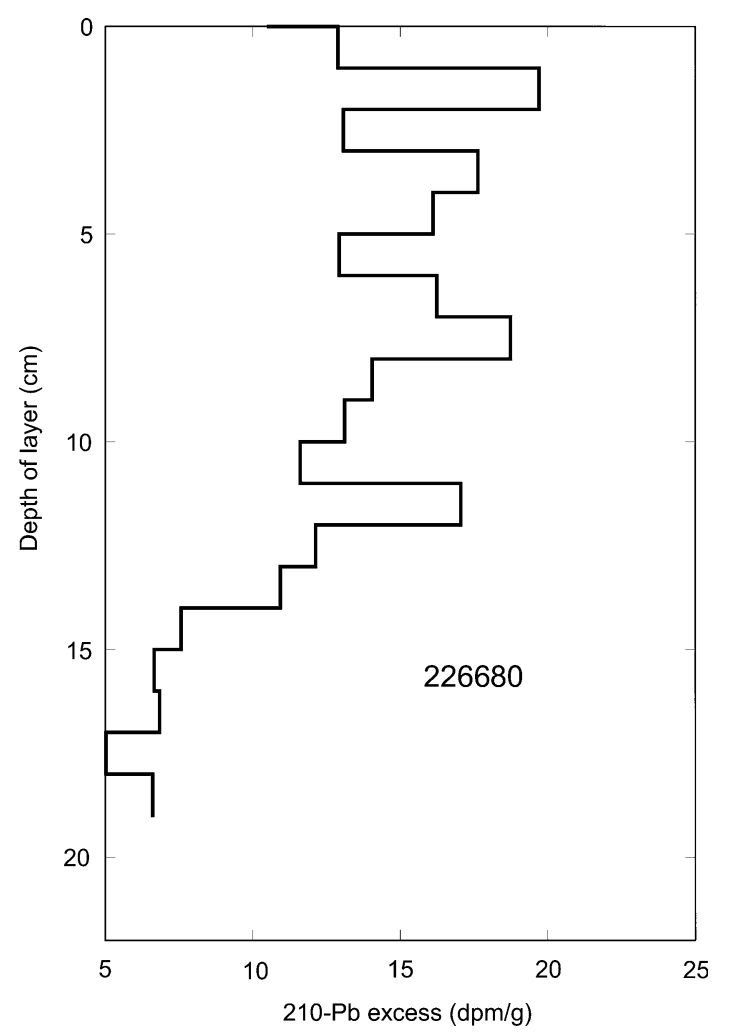

Fig. 2 An example of excess $210-\mathrm{Pb}$ profile with depth. For this station (226680), the excess ${ }^{210} \mathrm{~Pb}$ data from below $12 \mathrm{~cm}$ was used to estimate mass accumulation rates 
The frontal zone (ABFZ) between coastal upwelling and the tropical regime, which in the climatological mean state is located between 15 and $17^{\circ} \mathrm{S}$, is not well reflected in alkenone-based SST estimates due to poor sample coverage, but what little data are available suggest SST warmer than $20^{\circ} \mathrm{C}$ north of that frontal zone.

The patterns of proxy-derived SST in surface sediments thus generally conform to the SST signal seen in observational time series, both in SST range and in gradients. This makes alkenone unsaturation ratios a promising proxy for SST variations in the past and to decipher variability in the intensity and/or geographical location of upwelling. If the intensity of upwelling changed in the entire coastal upwelling system, for example in response to stronger or weaker SET, records from different areas should display synchronous SST variations; if
Fig. 3 Comparison of observed and proxy-based conditions in the upwelling area offshore Nambia. a Observed sea surface temperatures (SST, in ${ }^{\circ} \mathrm{C}$ ) (data from http://ioc.unesco.org/ oceanteacher/OceanTeacher2/ 07_Examples/examples.htm) and SST estimated from alkenone unsaturation ratios (b) in samples from 0 to $1 \mathrm{~cm}$ sediment depth. Alkenone data are from this study and from Müller et al. (1998). c Observed nitrate concentrations in surface waters (in $\mu \mathrm{mol} / \mathrm{l}$, left; data from http://ioc.unesco.org/ oceanteacher/OceanTeacher2/ 07_Examples/examples.htm) and surface sediment patterns of $\delta^{15} \mathrm{~N}$ (bulk sediment, in \%) d; shown are own data and data from Holmes et al. (2002). Locations of multicores are marked by crosses and core labels in $\mathbf{b}$ and $\mathbf{d}$
Temperature $\left[^{\circ} \mathrm{C}\right] @$ Depth $[\mathrm{m}]=T o p$

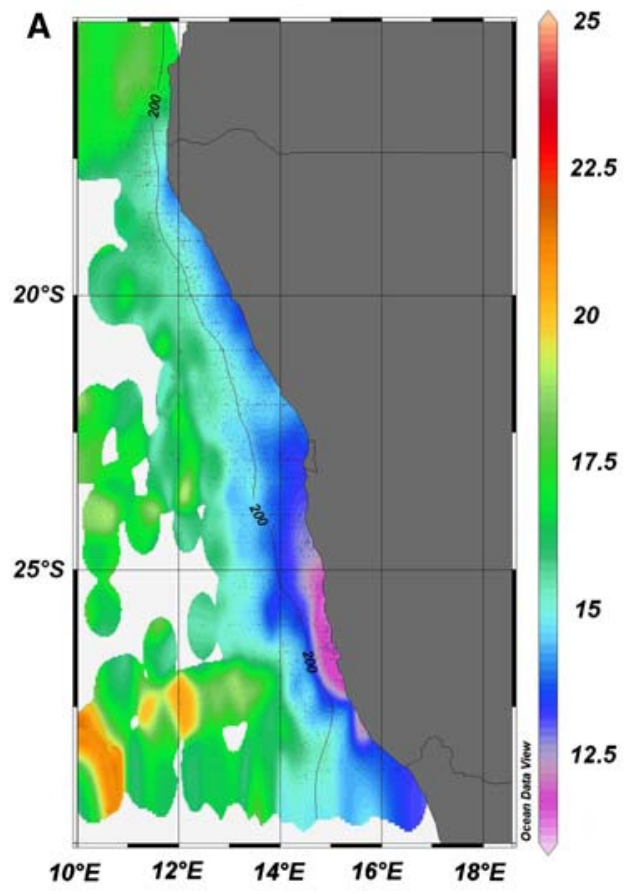

Nitrate [ $\mu \mathrm{mol} / \mathrm{I}]$ @ Depth [m]=Top

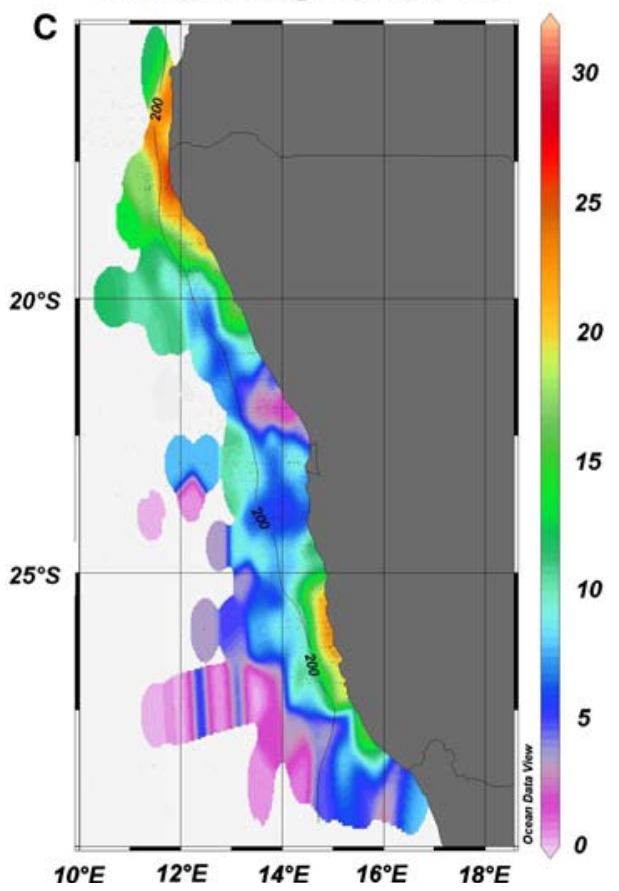

SST ( $\left.{ }^{\circ} \mathrm{C}\right) @$ Depth [m]=Bottom

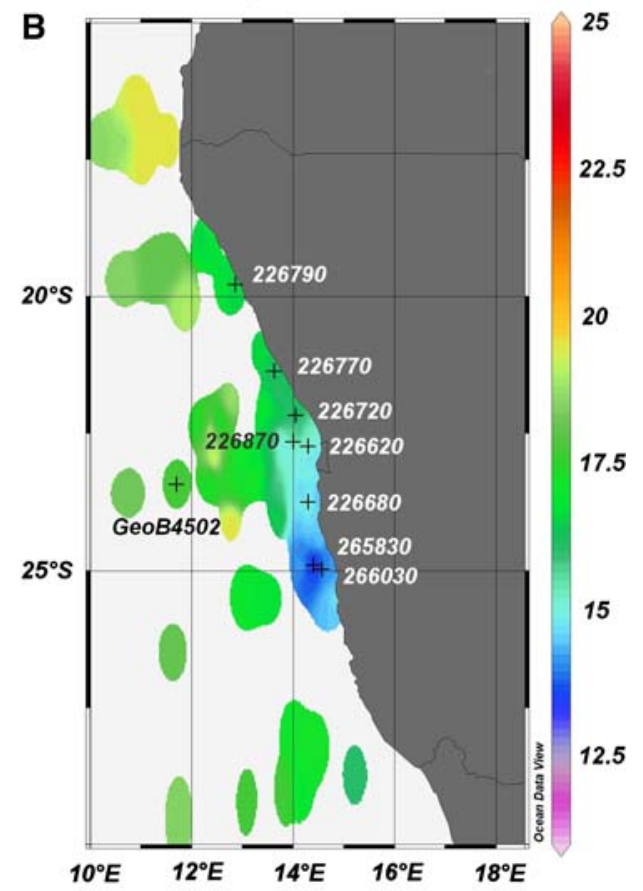

d15N@Depth $[\mathrm{m}]=B o t t o m$

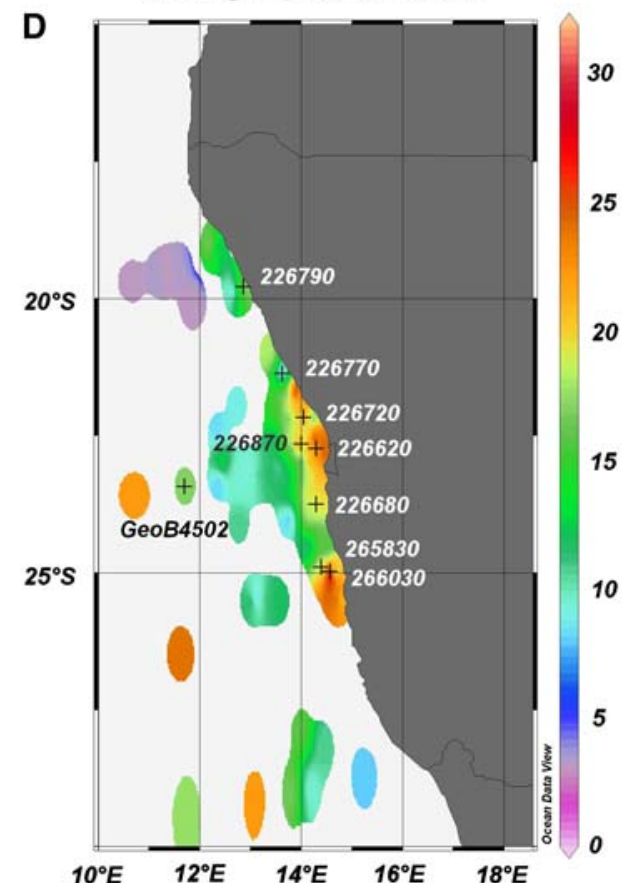


changes in individual upwelling cells were the reason for variability, we should see diverging spatial patterns.

A general assessment of spatial and intensity changes through time-albeit with a poorly constrained age control-within different sectors of the coastal upwelling system is shown in the four panels of Fig. 4. They show downcore alkenone SST estimates from nine multicores marked on the map. The time recorded in these records varies due to differences in sedimentation rates, and we will later investigate variations through time on several dated cores. An estimate for the age at the base of the multicores is given in the panels. This estimate uses the thickness of the Holocene section at each site and an age of 6,000 years for the basal shell layer. The ages for the deepest samples in the multicores were then calculated by linear interpolation. The basal age in multicore 226620 is an age determined by AMS- ${ }^{14} \mathrm{C}$.

That the changes recorded at the different sites are of different sign suggest that the alkenone unsaturation ratio is unaffected by diagenesis (Prahl et al. 1989) and that the records reflect SST variability in the past. The data reflect both proximity of the sampling location to upwelling cells, and changes in upwelling intensity of the upwelling cells through time: pristine upwelling water has a baseline SST of $12^{\circ} \mathrm{C}$, which is also seen in the present-day surface sediments as two discrete upwelling cells between 23 and $26^{\circ} \mathrm{S}$. Station 266030 (Fig. 3d) today is closest to the coldest upwelling water near Luederitz and has an estimated SST of $12.5^{\circ} \mathrm{C}$ in the core surface. Over the course of the record, the SST has remained cold at this location; overall SST variability here was less than $\pm 1^{\circ} \mathrm{C}$, and a slight trend $\left(-0.5^{\circ} \mathrm{C}\right)$ to colder conditions is seen towards younger sediments. The cooling trend is amplified in the second record from this southern area, station 265830; here, SST decreased from $15^{\circ} \mathrm{C}$ to slightly over $13^{\circ} \mathrm{C}$ over time. Being located somewhat more offshore, this location has apparently never recorded pristine upwelling mode water, but always warmed surface water advected from the general vicinity of station 266030 . The general tendency recorded by the two records in the southern sector around $25^{\circ} \mathrm{S}$ is thus one of cooling, consistent with an intensification of upwelling in the Luederitz cell over the last few centuries.

In contrast, records from the central Namibian upwelling cell $\left(24-22^{\circ} \mathrm{S}\right)$ registered a modest, but consistent increase in local SST by $2^{\circ} \mathrm{C}$ over the last centuries. This warming trend is well expressed in the record from station 226680 , which is only $100 \mathrm{~km}$ north of the cooling area. At the base of 226680 , SST was $14^{\circ} \mathrm{C}$ and thus only $1^{\circ} \mathrm{C}$ warmer than upwelling mode water; it increased by $1-2^{\circ} \mathrm{C}$ towards the top. The same warming tendency by $\sim 2^{\circ} \mathrm{C}$ more is seen in all records from the central cell, although each record started from a different baseline temperature that reflected the relative contribution of pristine upwelling water.

Two records in the northern sector (226770 and 226790) have no trend in SST and baseline SST here is above $15^{\circ} \mathrm{C}$ throughout the records. Both records vary around their means in a non-random manner and the record at 226770 in particular shows variations of $1{ }^{\circ} \mathrm{C}$ over the last centuries. On the other end of the SST range is site GeoB4502, which recorded SST variations in the outer fringes of the coastal upwelling system (see Fig. 3a). Unfortunately, we have no indication about the depth of the Holocene transgression layer at this site and no way to estimate the time covered by the core. SST here varied rapidly between 14 and $20^{\circ} \mathrm{C}$ with no obvious trend. The record is consistent with random interleaving of cold upwelling mode water and warm pelagic water over the site located in the offshore filament zone. Based on the patterns in multicores we may infer that upwelling activity in the vicinity of the dominant Luederitz upwelling cell has intensified, and has diminished in the area from 24 to $22^{\circ} \mathrm{S}$ (the central Namibian cell) over the last centuries. Position of and water mass character in the northern Namibian upwelling cell (represented by core 2266790) apparently have not changed over the last centuries.

Mass accumulation rates from six of the MUCs from the central and northern sectors have been estimated by fitting the lower $10-20 \mathrm{~cm}$ of the excess ${ }^{210} \mathrm{~Pb}$ distributions. Only sediment depths from below 10 to $15 \mathrm{~cm}$ are suitable for estimating mass accumlation rates using this model. It is clear from the ${ }^{210} \mathrm{~Pb}$ profiles that sedimentation is highly variable over time and that extensive mixing in the surface sediments is occurring, or that a significant change in sedimentation processes must have occurred over the last 50-100 years. Nevertheless, these estimates of sediment accumulation permit a more detailed assessment of variability over the last 150 years. The most highly resolved records from the northern sector (MUCs 226790 and 226770) show a gradual increase in SST over $1^{\circ} \mathrm{C}$ during the last 100 years (Fig. 5). Two of the records from the central area (MUCs 226870 and 226620) have decreasing SST over the last 50-100 years (by $\sim 1^{\circ} \mathrm{C}$ ). Two records from 22 to $23^{\circ} \mathrm{S}$ (MUCs 226720 and 226680) have seen increasing SST (by a maximum also of $1^{\circ} \mathrm{C}$ ). The spatial pattern seen in the SST changes is difficult to interpret, but it appears as though coastal upwelling has diminished in the northern sector over the last few decades, that the central Namibian cell near Walvis Bay has increased slightly in activity (as monitored by cores 226620 and 226870), and that the activity around this local upwelling centre has somewhat diminished. Surface sediment at location 226620 now marks the lowest SSTs, whereas these were registered at location 226680 some 50 years ago. 
Fig. 4 Downcore variations in estimated SST (from alkenone unsaturation ratios) for MUCs in different sectors of the upwelling area (depth scale in $\mathrm{cm}$ core depth) with estimated time periods covered by the records
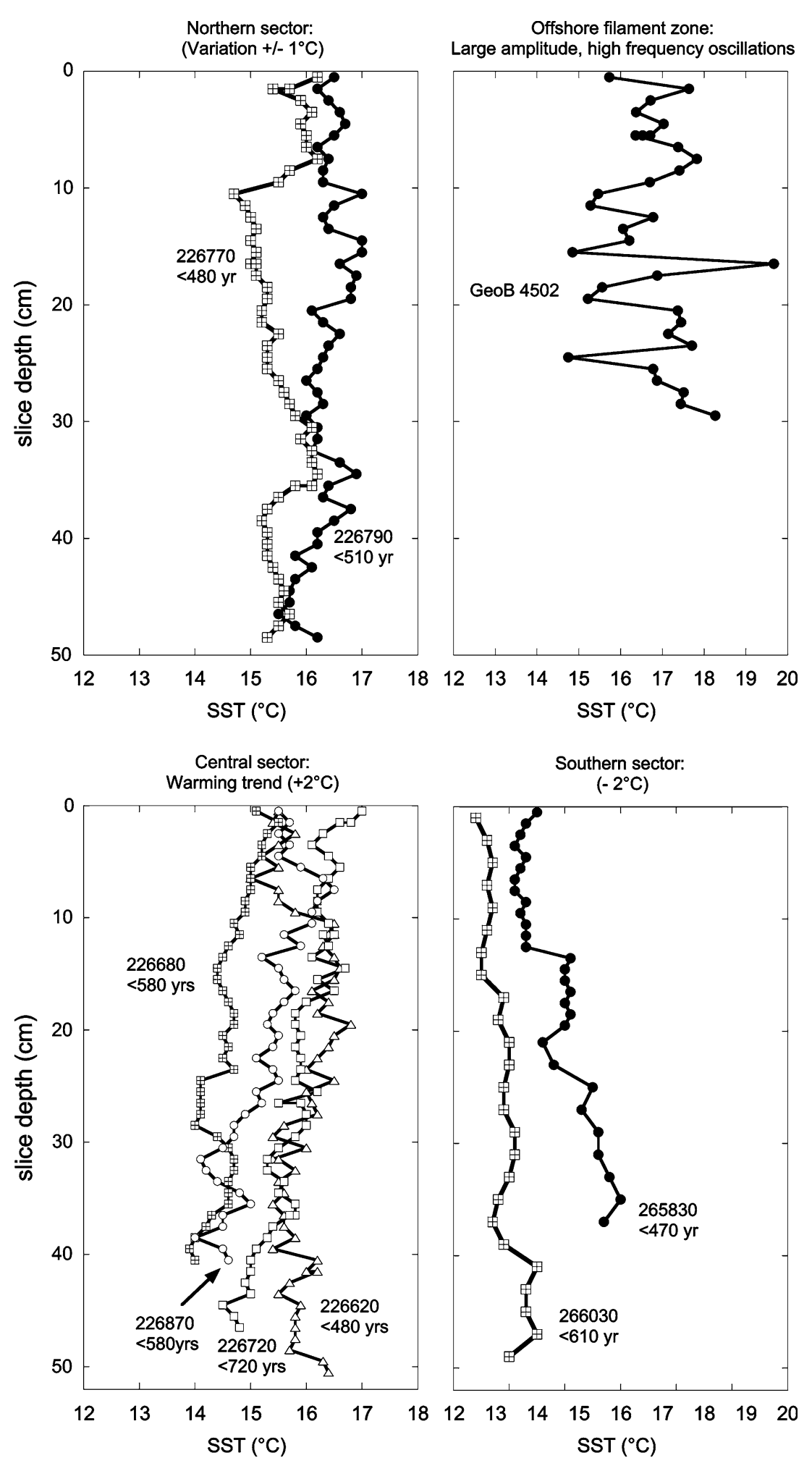

The records of SST variations together suggest that the upwelling system reacted inhomogeneously to changes in the external forcing, and that a general intensification/ weakening of the entire coastal upwelling system apparently was not the main cause of variability. A general intensification of upwelling in the entire system, caused for example by a general intensification of wind speed in the SET, would cause an overall cooling, or at least would not cause a warming in the central sector while the northern sector was unchanged. The records together thus suggest a 
Fig. 5 SST estimated from alkenone unsaturation ratios in multicores dated by $210-\mathrm{Pb}$ over the last 150 years
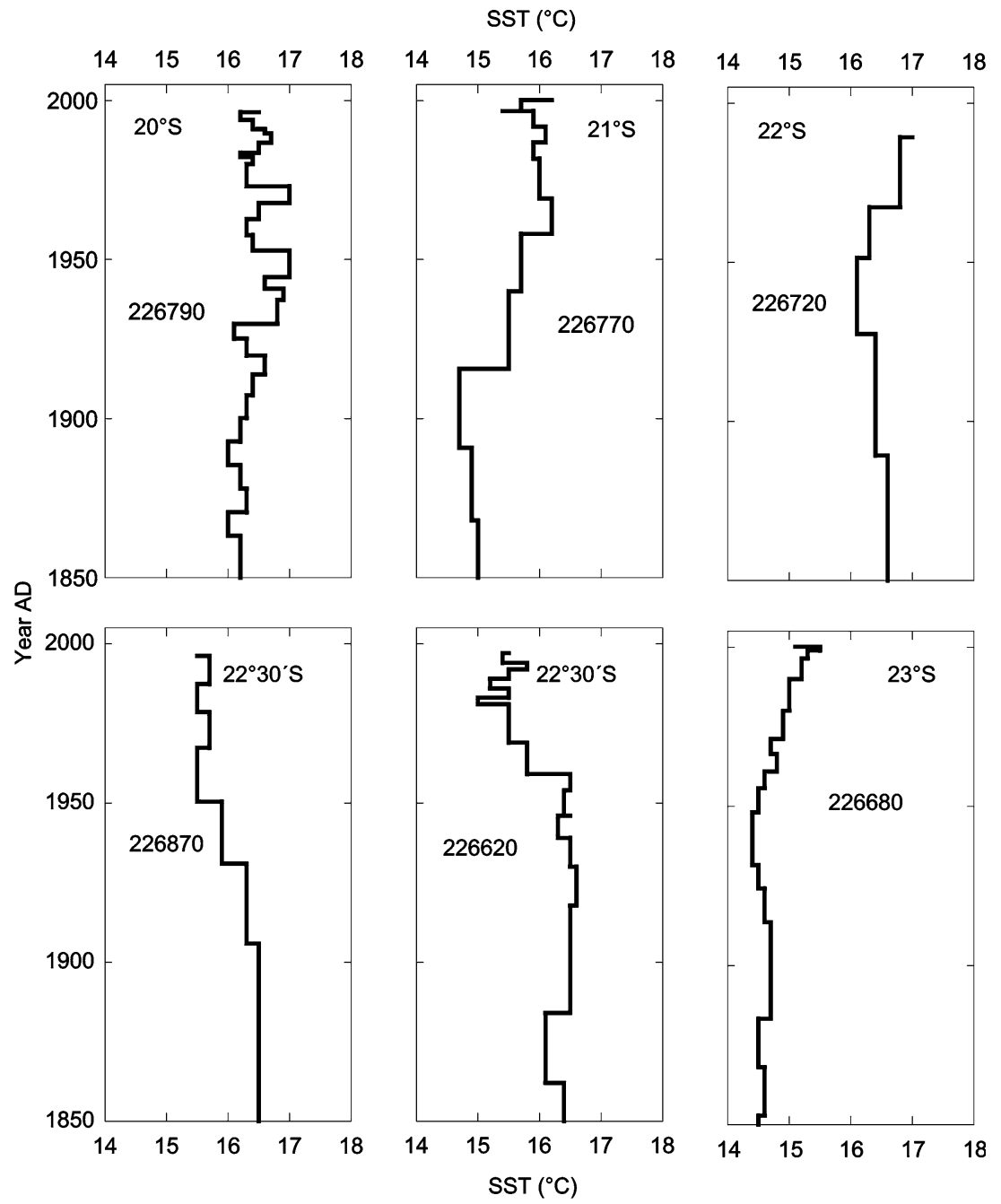

reorganisation of upwelling cells north of $25^{\circ} \mathrm{S}$ since 1900 A.D. Because such a reorganisation is unlikely to have been caused by changes in coastal morphology or seafloor topography, the only conceivable mechanism that would cause a change in the geographical position of upwelling cells is a change in wind stress curl.

Two dated SST records exist that span the time since 6,000 and 3,000 years, respectively. One core (NAM-1) has been published by Struck et al. (2002) and Baumgartner et al. (2004). Results for a second core (SL 226620; see Table 2 for the age model) encompass a longer period of time and are shown in Fig. 6. Comparing physical properties data and concentrations of TOC between the gravity corer and the multicorer taken at the same location suggests that $\sim 50 \mathrm{~cm}$ of sediment was lost by over-penetration in the gravity corer. At $19 \mathrm{~cm}$ core depth in the multicorer the age discrepancy between the 210-Pb-age and the interpolated $14 \mathrm{C}$-age is 40 years.

SST varied from $14^{\circ} \mathrm{C}$ to almost $20^{\circ} \mathrm{C}$ since 6,000 years ago, but the range of variation in the diatom ooze core interval, which is characteristic for shelf upwelling, is only around $2{ }^{\circ} \mathrm{C}$ and thus is similar in range to that seen in the multicores. After the Holocene transgression, present-day water depth was probably established by around 4,500 calendar years at the core location: Core intervals below $330 \mathrm{~cm}$ uncorrected depth (at $\sim 4,800$ cal years) are sandy and contain abundant bivalve and gastropod debris. High SST in combination with coarse sediment texture and abundance of shell debris in samples older than 4,800 cal years suggest that the site was situated in shallow water, possibly landward of the coastal upwelling. Sediments between 330 and $210 \mathrm{~cm}$ uncorrected depths (equivalent to 4,800-3,800 cal years) are laminated and/or colour banded on a sub-cm scale, implying that the site was bathed in anoxic to at least suboxic waters (Kiessling 2002). SST is quite variable in this sediment interval. Above $210 \mathrm{~cm}$ uncorrected depth (younger than 3,800 cal years), the laminations become more sporadic in the diatomaceous ooze and are completely absent in sediments above $110 \mathrm{~cm}$ core depth. This suggests that anoxia 


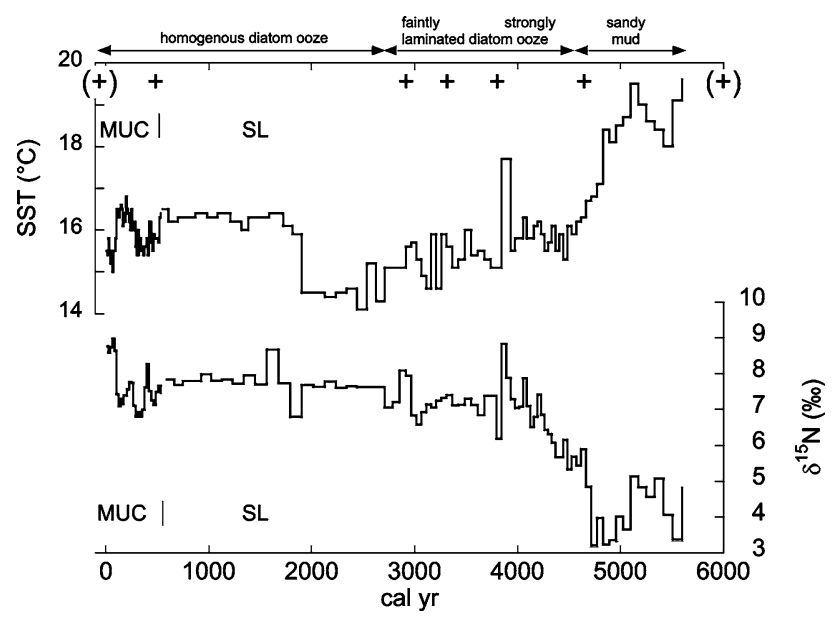

Fig. 6 Time series of SST and $\delta^{15} \mathrm{~N}$ in core 226620. The uppermost samples are from the corresponding multicore. Crosses mark 14-C age control points (see Table 2); age at the base of the core has been set to 6,000 years (linear extrapolation through lowermost four age dates)

apparently decreased in frequency of occurrence at around 2,700 cal years.

SST had decreased from 18 to $14.5^{\circ} \mathrm{C}$ by $1,900 \mathrm{cal}$ years with variations of around $\pm 1^{\circ} \mathrm{C}$. The temperature level of close to $14^{\circ} \mathrm{C}$ suggests that a centre of upwelling was intensifying in the vicinity of the core location; this intensification (cooling) was suddenly interrupted at $1,900 \mathrm{cal}$ years. At that time, SST stepped up by $1.5^{\circ} \mathrm{C}$, remained steady at $16^{\circ} \mathrm{C}$ until $500 \mathrm{cal}$ years and only in the multicore did the SST variability increase again, as discussed above.

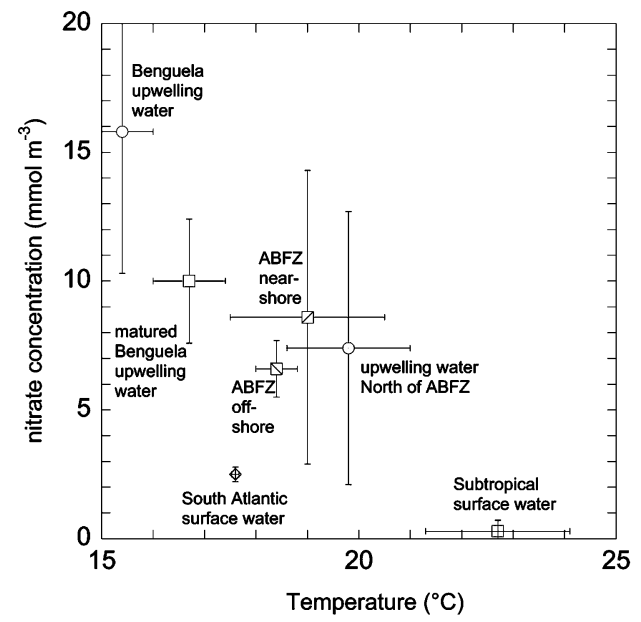

Fig. 7 a Ranges of nitrate concentrations plotted against temperatures of different water masses in the working area (data from Wasmund et al. 2005). ABFZ Angola-Benguela Frontal Zone. The plot shows the expected decreasing nitrate concentrations with increasing temperatures, as upwelled water warms and loses nitrate to assimilation by plankton. $\mathbf{b} \delta^{15} \mathrm{~N}$ ratios of surface sediment samples
Nutrient utilisation and denitrification intensity from $\delta^{15} \mathrm{~N}$

Sediments of the mud belt near the coast the coast and to water depths of $<150 \mathrm{~m}$ are enriched in ${ }^{15} \mathrm{~N}$, at both high (e.g. $\mathrm{S}^{\prime}$ of $25^{\circ} \mathrm{S}$ ) and low (e.g. around $22^{\circ} \mathrm{S}$ ) surface-water nitrate concentrations (Fig. 3c, d). Further offshore, where low nitrate concentrations occur in surface waters, the $\delta^{15} \mathrm{~N}$ of surface sediments is lower. This is intriguing, because we would expect an opposite pattern if nutrient utilisation alone were the dominant control on $\delta^{15} \mathrm{~N}$ : depleted $\delta^{15} \mathrm{~N}$ at high-nitrate concentrations, enriched sedimentary $\delta^{15} \mathrm{~N}$ at low nitrate concentrations. Overall, this is indeed the general relationship between proximity to upwelling cells and nitrate concentrations and is illustrated in Fig. 7a, where we plotted typical water masses in the area in terms of SST range and nitrate concentrations (data from Wasmund et al. 2005). This summary plot suggests that lowtemperature waters, indicating freshly upwelled waters, generally have the highest nitrate concentrations. But Fig. $3 \mathrm{c}$ also shows that in a more detailed view, the generally high nitrate concentrations in freshly upwelled waters are not necessarily found, and that some sectors of the coastal upwelling (between 20 and $25^{\circ} \mathrm{S}$ ) are clearly nitrate deficient. Interestingly, this is the area of the thickest mud accumulations and the highest $\delta^{15} \mathrm{~N}$ in surface sediments. In consequence, and opposite to what we expected, there is a negative correlation between SST estimates from alkenones and $\delta^{15} \mathrm{~N}$ in surface sediments $\left(r^{2}=0.44\right.$; Fig. $\left.7 b\right)$.

In addition to nutrient utilisation, another sink for nitrate and another cause for $\mathrm{N}$-isotope fractionation become evident from the spatial patterns seen in nitrate

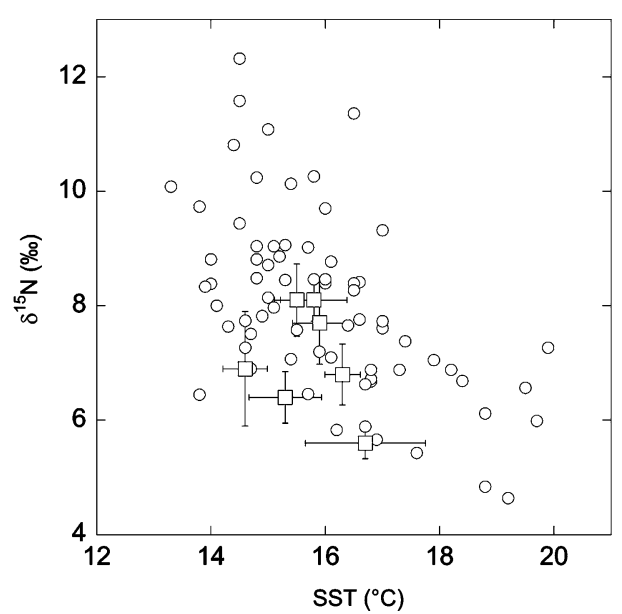

(circles) and of multicore samples (black squares with error bars) plotted against SST estimated from alkenone unsaturation ratios (this study). The negative correlation $\left(r^{2}=0.44\right)$ argues against nitrate utilisation as the dominant control for spatial patterns of $\delta^{15} \mathrm{~N}$ on the shelf and upper slope offshore Namibia 
concentrations at the sea surface (Fig. 3c). The area between 20 and $25^{\circ} \mathrm{S}$ on the shelf-where most of our sediment samples originate-coincides with an area of low-oxygen concentrations in the deeper water column. This coincidence strongly suggests that biological uptake is not the only mechanism that causes low-nitrate concentrations, and that denitrification combined with anaerobic ammonia oxidation (anammox) occurs in the water column at significant rates (Eichner 2001; Kuypers et al. 2005; Tyrrell and Lucas 2002).

The average $\delta^{15} \mathrm{~N}$-value of nitrate in the ocean today is about 5\% (Brandes and Devol 2002). In regions with a suboxic water column and denitrification in mid-watersuch as the Namibian coastal upwelling area-the lighter isotope is preferentially released as $\mathrm{N}_{2}$, and residual nitrate can have $\delta^{15} \mathrm{~N}$-values above 20\% (Altabet et al. 1999; Voß et al. 2001). Intriguingly, Eichner (2001) reported $\delta^{15} \mathrm{~N}_{\text {nitrate }}$ from two stations on the Namibian shelf that are between 4 and $8 \%$, so that a general enrichment of nitrate is most probably not the main reason for enriched surface sediment values; this leaves processes after deposition as the most likely cause for enrichment. On the other hand, Thunell et al. (2004) compiled data of paired concentrations and $\delta^{15} \mathrm{~N}$ of nitrate from the base of the respective euphotic zones of several suboxic, high-productivity continental margin settings under the influence of upwelling. The nitrate $\delta^{15} \mathrm{~N}$ ranged from 6 to $12 \%$, and had a 1:1 slope with $\delta^{15} \mathrm{~N}$ of surface sediments, showing no diagenetic offset. Until more measurements of $\delta^{15} \mathrm{~N}_{\text {nitrate }}$ become available from the Namibian system, we assume that the surface sediment values on the shelf reflect the isotopic signature of upwelling nitrate that has been isotopically enriched by denitrification in a suboxic water column. Our best estimate of the $\delta^{15} \mathrm{~N}_{\text {nitrate }}$ of upwelling water is around $12 \%$, but is in conflict with data of Eichner (2001).

The $\delta^{15} \mathrm{~N}$ range in the surface sediments on the shelf and adjacent slope are surprising, because they are not in accord with a significant contribution of DIN from the coastal upwelling upwelling to DIN in the adjacent ocean. If we assume that some of the DIN in the offshore waters originates from coastal upwelling, we expect to see an effect of nutrient utilisation that should result in lower values than 12\% near the coast (Holmes et al. 1997). Because a $\delta^{15} \mathrm{~N}$ of $10 \%$ in the accumulated biomass (and surface sediment) is reached when roughly $80 \%$ of the upwelled nitrate with presumed initial $12 \% 0 \delta^{15} \mathrm{~N}$ is assimilated, the data have an important consequence: Because $\delta^{15} \mathrm{~N}$ of the remaining nitrate should have $21 \%$, the upwelling nitrate cannot be a significant DIN source for biomass produced offshore, where surface sediment $\delta^{15} \mathrm{~N}$ is much lighter. The data thus suggest that coastal upwelling is unlikely to be a source of nitrate for the adjacent ocean.
Whereas the belt of high $\delta^{15} \mathrm{~N}$ on the shelf is consistent with assimilation of nitrate that has undergone denitrification, there must be additional DIN sources with low $\delta^{15} \mathrm{~N}$ signatures feeding the offshore waters. The candidates are shelf-edge upwelling processes (Barange and Pillar 1992; Summerhayes et al. 1995b; Holmes et al. 1998; Pichevin et al. 2005), nitrogen fixation in the outer fringes of the coastal upwelling cell (for which there is no independent evidence), or advection of particulate nitrogen with low $\delta^{15} \mathrm{~N}$ from outside the upwelling system. An indication for the latter process may be the cluster of low ratios found around $20^{\circ} \mathrm{S}$, in water depths around $500 \mathrm{~m}$, because this feature cannot be fuelled by upwelling nitrate from the coastal cells. Instead it may reflect some other, isotopically depleted particulate nitrogen source. The feature coincides with the path of low-oxygen water in the poleward undercurrent that may advect particulate $\mathrm{N}$ in near-bottom transport processes.

How do sediment records reflect nutrient utilisation and denitrification/anammox in the past? In the sediment cores, there is no simple positive relationship between SST and $\delta^{15} \mathrm{~N}$ expected from nutrient utilisation alone, but neither is the negative correlation between the two variables seen in surface sediments (Fig. 7b) consistently seen in the cores (Fig. 8). On the positive side, none of the cores exhibited $\delta^{15} \mathrm{~N}$-values that exceeded the range found in surface sediments today. Furthermore, the data from the multicores plot within the same range, and in the same general trend of decreasing $\delta^{15} \mathrm{~N}$ at increasing SST, as was seen in the surface sediments (Fig. 7b). We argue that the lack of a relationship between SST (as an indicator of proximity to upwelling) and $\delta^{15} \mathrm{~N}$ seen in the the multicore records is an indication of the overriding control of denitrification/ anammox in determining both the amount of nitrate available for uptake and the isotopic signature of sedimentary $\delta^{15} \mathrm{~N}$.

The nitrogen cycle in different sectors of the coastal upwelling system responded differently to upwelling changes indicated by SST variations (Fig. 8). With the possible exception of core 226770, all records registered an increase in $\delta^{15} \mathrm{~N}$ in the youngest sediments, regardless of the sense and magnitude of SST changes. The increase in $\delta^{15} \mathrm{~N}$ in youngest samples suggests a higher degree of denitrification and implies a deterioration of the oxygen supply to the shelf. In detail, however, the different locations have different evolutions. In the vicinity of the Walvis Bay upwelling cell, locations 226870 and 226620 recorded a decrease in SST concomitant with an increase in denitrification over the upper $10 \mathrm{~cm}$ interval. This suggests increased entrainment of colder and more oxygen-depleted waters. Locations 226720 and 226680, bracketing this intensified upwelling cell, have warming tendencies associated with increased denitrification. This suggests a 
Fig. 8 Trends $\delta^{15} \mathrm{~N}$ in multicores with SST determinations on the same samples
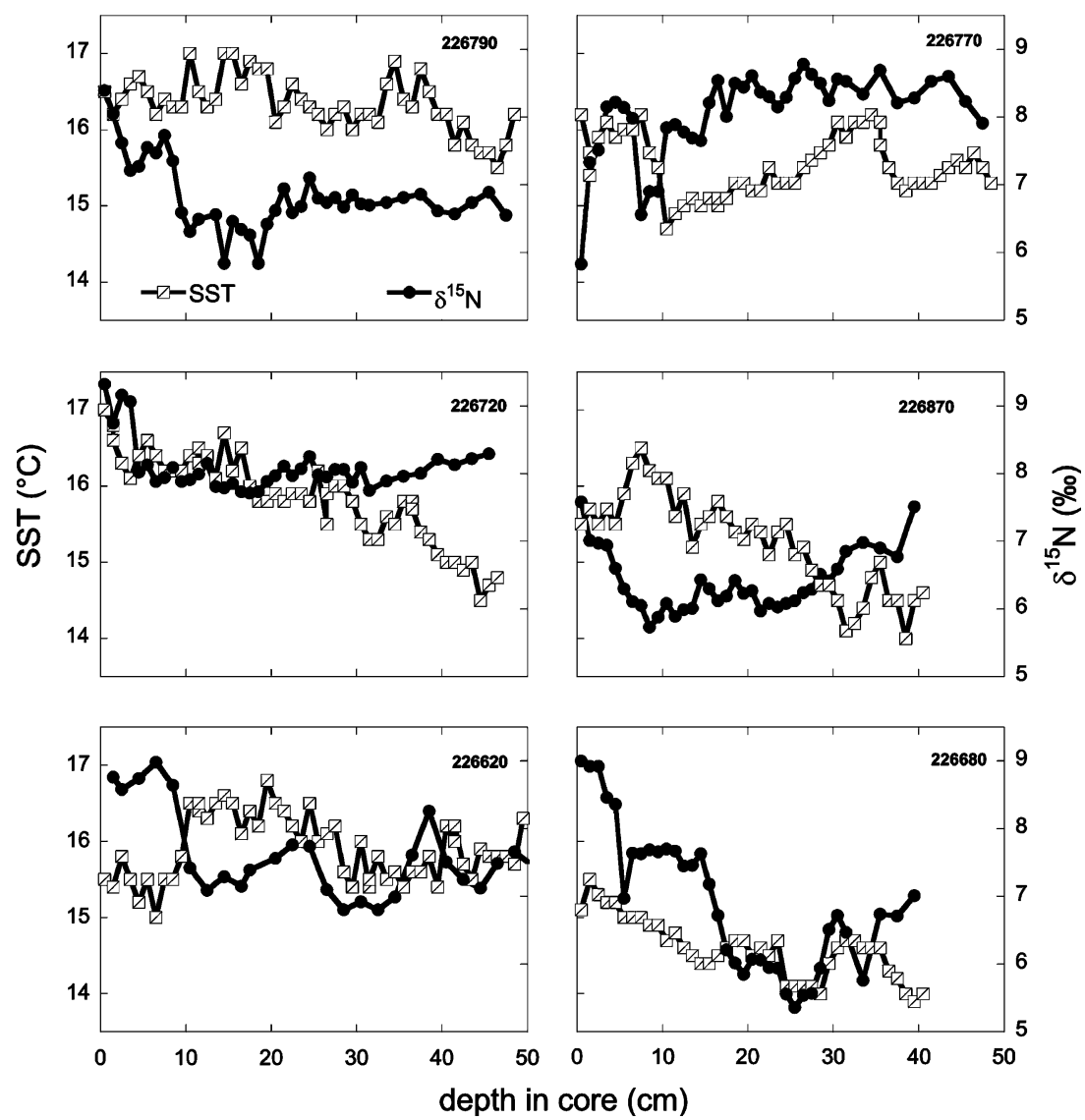

spreading of oxygen depleted conditions over the immediate vicinity of intensified upwelling. In the northern part of the mud lens, core 226790 registered the largest signal of increased denitrification ( $\delta^{15} \mathrm{~N}$ increased by $3 \%$ ), but SST remained largely invariant. Core 226770, which showed cyclic variations in SST, resembles none of the other records and recorded little change in $\delta^{15} \mathrm{~N}$. Our current hypothesis is that entrainment of $\mathrm{O}_{2}$-deficient waters from the poleward undercurrent increased in locally intensified upwelling cells.

When the data is plotted against time in those multicores for which a $210-\mathrm{Pb}$ age model exists, we note that $\delta^{15} \mathrm{~N}$ increased over the last 50-100 years in the entire upwelling area (Fig. 9). The increase is first seen in the high-resolution record of core 226680, where it began in the 1930s; by 1950 it had reached the central stations and was registered at the northern locations since the 1960s. On a much longer timescale, the time series of nitrogen isotopes in gravity core SL 226620 is almost a mirror image of the SST evolution (Fig. 6). This long record as well has a range of $\delta^{15} \mathrm{~N}$ as that seen in modern surface sediments. Starting with low $\delta^{15} \mathrm{~N}$ in the sands and sandy muds of the transgression facies, variability was high to 2,600 cal years and $\delta^{15} \mathrm{~N}$ varied from 5 to $9 \%$ in the laminated oozes. After that time no laminations occur and the homogeneous diatom oozes suggest less intense anoxia. The $\delta^{15} \mathrm{~N}$-values are uniform at around 7\%o after 2,600 years and variability only started to increase again at $\sim 500$ cal years, corresponding to the base of the multicore at the same location.

Past variability in forcing and upwelling: evidence from observations

A synopsis of evidence for variations in forcing on seasonal to interannual time scales since the 1980s has been recently published by Hardman-Mountford et al. (2003) for the Northern Benguela region. These authors evaluated time series of satellite data and of numerical model products. According to the analysis, ocean climate in the South East Atlantic and along the coast of Africa is forced from both the northern and southern boundaries. From the North, seasonal signals of equatorial origin invade along the Angolan coast, while the trade winds and events in the Agulhas region dominate the Southern Benguela. The Northern Benguela-our area of interest-is a mixed regime, under the influence of forcing from both directions. Seasonal and interannual variability over the shelf is high, as seen in high standard deviations of wind stress, SST, and chlorophyll concentrations. Variability on interannual time 
Fig. $9 \delta^{15} \mathrm{~N}$ in $210-\mathrm{Pb}$ dated multicores versus time all display an upward increase in $\delta^{15} \mathrm{~N}$, suggesting an increase in denitrification and a decrease in oxygen supply to the shelf area, starting around $\mathrm{AD} 1950$

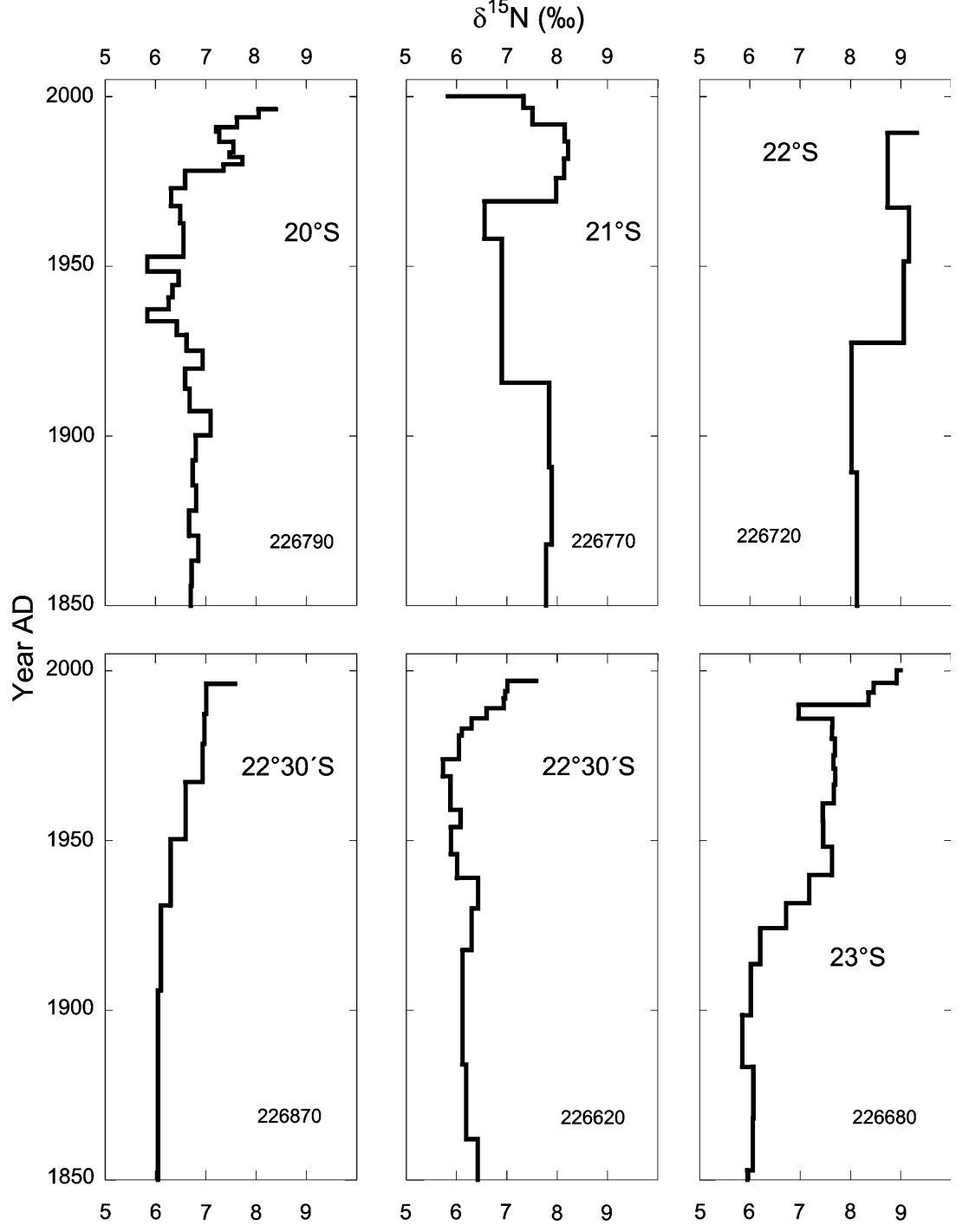

scales is dominated by Benguela Niños, which are clearly observed in positive SST and sea level anomalies; they coincide with anomalously weak southerly winds at the equator. During years with an exceptionally relaxed SET intensity, the ABFZ is extremely displaced southwards. In addition, an eastward travelling equatorial Kelvin wave transports warm, saline waters from the western tropical Atlantic towards the Gulf of Guinea and the ABFZ reaches extreme southern positions to drastically reduce the overall belt of the Benguela upwelling (Shannon et al. 1986). This analogue to the El Niño in the eastern Pacific is called Benguela Niño. On the interannual scale, such events have approximately the same temporal recurrence as those observed in the Pacific.

The warm surface water reaches latitudes as far south as $25^{\circ} \mathrm{S}$. It causes positive sea-level anomalies of up to $5 \mathrm{~cm}$ at Walvis Bay (Shannon and Nelson 1996). Inflow of warm waters raises SST by $2-8^{\circ} \mathrm{C}$ in the northern sector of the Benguela upwelling system. Increased SSTs during
Benguela Niños cause increased evaporation and enhance the upward directed atmospheric convection: small atmospheric cyclones mark the track of the warm water and lead to increased precipitation on land. Prominent Benguela Niños were observed in the years 1963, 1974, 1984, 1993, 1996, 1997 and 1999. Additional events were reconstructed from historical records for the years 1892, 1908/1909, 1922/1923, 1934, 1937, 1949 and 1953 (Hagen et al. 2001). The average time interval between all consecutive extreme years was about 11 years between 1909 and 1963, but only 5 years between 1974 and 1999 .

Feistel et al. (2003) used meteorological data from St. Helena Island to derive an index describing the relative activity of the SAA. Because the SET wind results from gradients in air pressure between the SAA and low pressure of the ITCZ in the North and those between the SAA and the Angola-Kalahari Low in the East, changes in position and intensity of these atmospheric centres cause the variability in the SET at different scales of space and time. 
Substantial changes in the alongshore component of the SET cause anomalously strong or weak coastal upwelling on different spatial and temporal scales in the coastal upwelling system.

To extend the record of climatic variability in the upwelling area, Feistel et al. (2003) assembled and homogenised the St. Helena 1893-1999 century-long monthly weather records of temperature, pressure and rainfall. The resulting time series exhibits trends for decreasing precipitation $(10 \mathrm{~mm} / 100$ year), increasing air temperature $\left(0.9^{\circ} \mathrm{C} / 100\right.$ year), and decreasing air pressure $(0.6 \mathrm{hPa} / 100$ year). The first empirical orthogonal eigenfunction (EOF) explained $46 \%$ of the total variance in the data set and its associated temporal coefficient was termed 'St. Helena Island Climate Index' (HIX) (Fig. 10). In addition to known Benguela Niño events and those events reconstructed from historical records, the HIX time series in addition suggests Benguela Niños for the years 1895, 1905, 1912, 1916 and 1946. When comparing austral winter HIX with an index describing the intensity of coastal upwelling, it was found to have a statistically significant correlation with remotely sensed SST expressed as the Benguela upwelling index, called IBU (Hagen et al. 2005). The IBU is based on the spatial variations in the extent of $<13^{\circ} \mathrm{C}$ water over the shelf (Hagen et al. 2001). Observations on the areal extent of the $13^{\circ} \mathrm{C}$ isotherm identified the following years of strong Benguela upwelling events: 1982, 1985, 1990 and 1992. The years 1911, 1922, 1967 and 1976 were proposed as intensive upwelling years based on the HIX (Fig. 10).

Matching observations with the sediment record

Interestingly, SST apparently have not changed synchronously over the entire coastal upwelling system as a whole, but the system has behaved differently in different sectors. Satellite SST data analysed by Hagen et al. (2001) showed a similar segregation into regionally diverging patterns of SST as we see in the dated portion of the records. The second mode of variability in the IBU indicated that a warming in the North coincides with a cooling in the South and vice versa. The third mode was barely significant and its eigenfunction divided the study area into three subregions: $17-22,22-30$ and $30-34^{\circ} \mathrm{S}$. It suggested that warming in the central zone should be accompanied by cooling in the northern and southern zones and vice versa, similar to what we see on a completely different time scale in the diverging SST records of multicores.

The time period covered in the dated cores is the same as that covered by the HIX time series with its series of cold and warm events. However, that data set does not contain the long-term trends that characterise the sediment

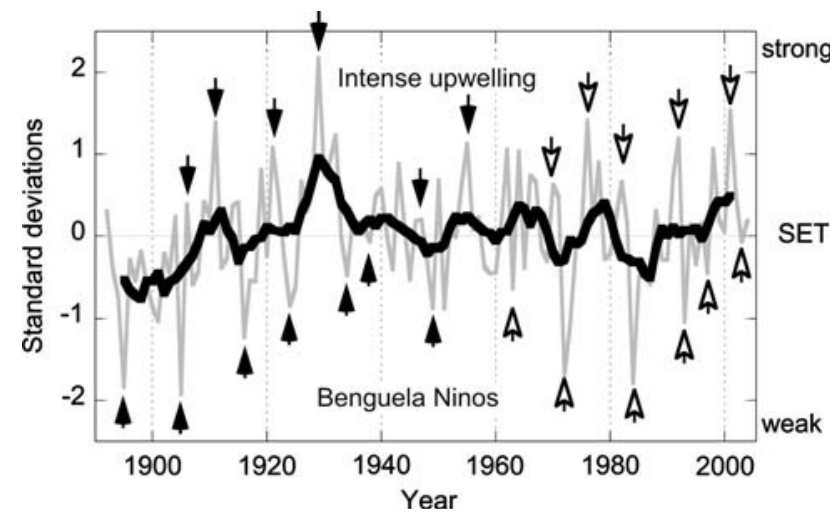

Fig. 10 Time series of the St. Helena Climate Index (Feistel et al. 2003). Grey curve are monthly average values of the HIX climate index for austral winter months July, August and September. The black line marks a running average over 7 years. Negative values denote weak SET intensity, positive values denote strong SET intensity. Filled arrows denote inferred Benguela Niños and intense upwelling, empty arrows denote observed events (redrawn after Hagen et al. 2005)

records. In cores near the northern Angola-Benguela Front, we find variations in SST of $1{ }^{\circ} \mathrm{C}$ that co-varied reasonably well with the annual average of the HIX. However, the sediment record of SST did not trace the frequency of positive (Benguela Niños) or negative (Intense Benuela Upwelling) upwelling indexes, possibly because they appear to both cluster at certain times and either cancel each other out in the sediment record, or because the highfrequency signal is attenuated by processes in the sediments. At our present state of knowledge and data, it is difficult to extrapolate from observational time series (and derived reconstructions of atmospheric circulation and upwelling intensity) to sedimentary archives, and vice versa.

Possible causes for long-term variations

The underlying causes for the decadal-scale variability are not agreed upon. Clearly that variability has to include atmosphere-ocean interactions, and several likely candidates have been identified by Marshall et al. (2001). These all influence the interhemispheric SST differences that are a basic control for the relative intensities and position of trade wind systems on the Northern and Southern hemispheres. Candidates are the North Atlantic Oscillation (NAO) in the mid-latitudes of the North Atlantic that reaches down into the tropical climate system by changing the strength and position of the Azores High, positive feedbacks in the system wind-evaporation-SST on regional scales, or anomalous heat fluxes that reinforce initial interhemispheric gradients in SST and thus strengthen crossequatorial wind anomalies (Chang et al. 1997). Whatever 
the most important mechanism is, it is clearly linked to variability in heat fluxes between ocean and atmosphere, which alter circulation not only in the atmosphere, but also in the ocean on a global scale. That means that decadal scale changes in climatic conditions establish/maintain teleconnections over far distances via self-sustaining dynamics (Deser and Blackmon 1993; Miller and Schneider 2000; Montecinos et al. 2003).

Cross-equatorial heat flux in the Atlantic Ocean, both in the atmosphere and in the ocean, creates strong links between processes in the trade-wind driven coastal upwelling, the tropical climate system, and processes in the North Atlantic (Marshall et al. 2001). Variability there is driven by changes in the NAO, in meridional overturning circulation, and thus essentially again in heat flux (Delworth and Greatbatch 2000). This is the gist of recent theoretical work published by Prange and Schulz (2004), who modelled the responses of the two African upwelling systems to changes in cross-equatorial heat transport. According to the model results, the two systems operate in a see-saw mode, where one upwelling system is strengthened at the expense of the other. Although their perturbation experiments were on comparatively large (shutdown of North Atlantic Thermohline Circulation) to huge scale (closure of the Isthmus of Panama), the results nevertheless suggest that any process affecting the meridional heat transport in the Atlantic Ocean should have an effect on the upwelling systems.

\section{Conclusions}

The performance of coastal upwelling systems of the Atlantic Ocean in terms of carbon sequestration, greenhouse gas release/consumption and ecosystem structure and yield is intimately linked to physical forcing by largescale atmospheric circulation patterns. These hemispheric atmospheric patterns in turn are linked to meridional, crossequatorial heat transfer. The pivotal property that links the physical domain in the coastal upwelling area offshore Namibia to the chemical and ecosystem domains is the oxygen content of the water column, which is affected by physical forcing and internal biogeochemical processes. Based on observation time series, intense variability in forcing and in upwelling intensity have been recognised. Likewise, the oxygen supply to the shelf appears to have undergone significant changes. Sedimentary archives suggest that SST variability over the last several thousands of years was within the bounds of today's conditions, but that regional heterogeneity in SST and biogeochemical conditions was significant. Nitrogen isotope data shed some doubt on both the significance of $\delta^{15} \mathrm{~N}$ as a proxy for nutrient utilisation, and on the role of coastal upwelling as a source of nutrients for the adjacent ocean. The data suggest a predominant influence of denitrification/anammox on $\delta^{15} \mathrm{~N}$ ratios, and this accepted, suggest a decrease in oxygen supply to the shelf offshore Namibia over the last 50 years. All this preliminary evidence both highlights the needs for future studies and underscores the potential of studies in the coastal upwelling system offshore Namibia to address key questions of the IMBER initiative.

Acknowledgments The authors acknowledge funding by the DFG (contracts DFG Em 37/13, 23) and the University of Hamburg (Valdivia-Schwerpunkt). K. E. thanks the Japanese Society for the Advancement of Science for a travel grant, and the IFREE four groups for their hospitality during a stay in Yokosuka/Japan, during which the paper was written. We thank R. Rosenberg, S. Lage, I. Stottmeister (Warnemünde) and R. Ebbinghaus (Hamburg) for the analyses. R. Feistel (Warnemünde) provided the HIX data. Discussion with E. Hagen, V. Mohrholz and J. Alheit (Warnemünde) helped to put the manuscript together. Reviews by G. Mollenhauer and R. Schneider are gratefully acknowledged.

\section{References}

Altabet MA, Francois R (1994) The use of nitrogen isotopic ratio for reconstruction of past changes in surface ocean nutrient utilization. In: Zahn R, Pedersen TF, Kaminski MA, Labeyrie L (eds) Carbon cycling in the glacial ocean: constraints on the oceańs role in global change. NATO ASI series. Springer, Heidelberg

Altabet MA, Murray DM, Prell WL (1999) Climatically linked oscillations in Arabian Sea denitrification over the past 1 m.y.: implications for the marine $\mathrm{N}$ cycle. Paleoceanography 16(6):732-743

Bailey GW (1991) Organic carbon flux and development of oxygen deficiency on the modern Benguela continental shelf south of $22^{\circ} \mathrm{S}$ : spatial and temporal variability. In: Tyson RV, Pearson TH (eds) Modern and ancient continental shelf anoxia. The Geological Society, London, pp 171-183

Barange M, Pillar SC (1992) Cross-shelf circulation, zonation and maintence mechanisms of Nyctiphanes capensis and Euphausia hanseni (Euphausiacea) in the northern Benguela upwelling system. Continental Shelf Res 12(9):1027-1042

Baumgartner TR, Struck U, Alheit J (2004) GLOBEC investigation of interdecadal to multi-centennial variability in marine fish populations. GLOBEC Newsl 12(1):19-21

Berger WH, Smetacek VS, Wefer G (eds) (1989) Productivity of the ocean: present and past. Wiley, Chichester, p 471

Blanz T, Emeis K-C, Siegel H (2005) Controls on alkenone unsaturation ratios along the salinity gradient between the open ocean and the Baltic Sea. Geochim Cosmochim Acta 69(14):3589-3600

Boyd AJ, Salt J, Masó M (1987) The seasonal intrusion of relatively saline water on the shelf off northern and central Namibia. S Afr J Mar Sci 5:107-120

Brandes JA, Devol AH (2002) A global marine-fixed nitrogen isotopic budget: implications for Holocene nitrogen cycling. Global Biogeochem Cycles 16(4):10.1029/2001GB001856

Brassell SC, Eglinton G, Marlowe IT, Pflaumann U, Sarnthein M (1986) Molecular stratigraphy: a new tool for climatic assessment. Nature 320:129-133

Bremner JM (1983) Biogenic sediments on the SW African (Namibian) continental margin. In: Thiede J, Suess E (eds) Coastal upwelling: its sediment record. Part B: sedimentary records of ancient coastal upwelling. Plenum Press, New York, p 610 
Brown PC, Paintings SJ, Cochrane KL (1991) Estimates of phytoplankton and bacterial biomass and production in the northern and southern Benguela ecosystems. S Afr J Mar Sci 11:537-564

Carpenter R, Peterson ML, Bennett JT (1982) 210Pb-derived sediment accumulation and mixing rates for the Washington continental slope. Mar Geol 48:135-164

Chang P, Ji L, Li H (1997) A decadal climate variation in the tropical Atlantic from thermodynamic air-sea interactions. Nature 385:516-518

Chapman P, Shannon L (1987) Seasonality in the oxygen minimum layers at the extremities of the Benguela system. S Afr J Mar Sci 5:11-34

Chavez FP, Ryan J, Lluch-Cota DB, Niquen M (2003) From anchovies to sardines and back: multidecadal change in the Pacific Ocean. Science 299:217-221

Delworth T, Greatbatch RJ (2000) Multidecadal thermohaline circulation variability driven by atmospheric surface flux forcing. $\mathrm{J}$ Clim 13:1481-1493

Deser C, Blackmon ML (1993) Surface climate variations over the North Atlantic Ocean during winter. J Clim 6:1743-1753

Diffenbaugh NS, Snyder MA, Sloan L (2004) Could $\mathrm{CO}_{2}$-induced land-cover feedbacks alter near-shore upwelling regimes? Proc Nat Acad Sci 101(1):27-32

Eichner C (2001) Mikrobielle modifikation der isotopensignatur des stickstoffs in marinem partikulärem material. Marine Science Reports, 44. Ph.D. Dissertation, Inst. Baltic Sea Research, Rostock, FRG, p 122

Emeis K-C, Brüchert V, Currie B, Endler R, Ferdelman T, Kiessling A, Leipe T, NoliPeard K, Struck U, Vogt T (2004) Shallow gas in shelf sediments of the Namibian coastal upwelling ecosystem. Continental Shelf Res 24(6):627-647

Feistel R, Hagen E, Grant K (2003) Climatic changes in the subtropical Southeast Atlantic: the St. Helena Island climate index (1893-1999). Prog Oceanogr 59(2-3):321-337

Fennel W (1999) Theory of the Benguela upwelling system. J Phys Oceanogr 29:177-190

Gaye-Haake B, Lahajnar N, Emeis K-C, Rixen T, Unger D, Schulz H, Ramaswamy V, Paropkari AL, Guptha MVS, Ittekkot V (2005) Stable nitrogen isotopic ratios of sinking particles and sediments from the northern Indian Ocean. Mar Chem 96:243-255

Gouretski VV, Koltermann KP (2004) WOCE global hydrographic climatology. 35, Berichte des Bundesamtes für Seeschifffahrt und Hydrographie Nr. 35/2004, Hamburg

Hagen E, Feistel R, Agenbag JJ, Ohde T (2001) Seasonal and interannual changes in intense Benguela upwelling (1982-1999). Oceanol Acta 24(6):557-568

Hagen E, Agenbag JJ, Feistel R (2005) The winter St. Helena climate index and extreme Benguela upwelling. J Mar Syst 57:219-230

Hardman-Mountford NJ, Richardson AJ, Agenbag JJ, Hagen E, Nykjaer L, Shillington FA, Villacastin C (2003) Ocean climate of the South East Atlantic observed from satellite data and wind models. Prog Oceanogr 59:181-221

Hentschel E (1936) Allgemeine biologie des südatlantischen Ozeans. In: Defant A (ed) Wissenschaftliche Ergebnisse der Deutschen Atlantik expedition auf dem Forschungs-und vermessungsschiff "Meteor" 1925-1927. de Gruyter \& Co., Berlin, pp 1-343

Holmes ME, Müller PJ, Segl M, Wefer G (1997) Reconstruction of past nutrient utilization in the eastern Angola Basin based on sedimentary ${ }^{15} \mathrm{~N} /{ }^{14} \mathrm{~N}$ ratios. Paleoceangraphy 12(4):604-614

Holmes ME, Müller PJ, Schneider RR, Segl M, Wefer G (1998) Spatial variation in euphotic zone nitrate utilization based on $\delta^{15} \mathrm{~N}$ in surface sediments. Geomarine Lett 18(1):58-65

Holmes ME, Müller PJ, Schneider RR, Segl M, Wefer G (2002) Stable nitrogen isotopes in surface sediments of the Benguela upwelling system. Geomarine Lett 18(1):58-65
Kiessling A (2002) Sedimentphysikalische Eigenschaften auf dem Schelf und oberen Kontinentalrand von Namibia-Auswertung von Sedimentkernen der Reise METEOR 48-2. M. Sc. Thesis, Greifswald University, Greifswald, p 66

Kuypers MMM, Lavik G, Woebken D, Schmid M, Fuchs BM, Amann R, Jørgensen BB, Jetten MSN (2005) Massive nitrogen loss from the Benguela upwelling system through anaerobic ammonium oxidation. PNAS 102(18):6478-6483

Lass HU, Schmidt M, Mohrholz V, Nausch G (2000) Hydrographic and current measurements in the area of the Angola-Benguela Front. J Phys Oceanogr 30:2589-2609

Lehmann MF, Bernasconi S, Barbieri A, McKenzie JA (2002) Preservation of organic matter and alteration of its carbon and nitrogen isotope composition during simulated and in situ early sedimentary diagenesis. Geochim Cosmochim Acta 66(20):3573-3584

Lehmann MF, Sigman DM, McCorkle DC, Brunelle BG, Hoffmann S, Kienast M, Cane G, Clement J (2005) The origin of the deep Bering Sea nitrate deficit-Constraints from the nitrogen and oxygen isotopic composition of water-column nitrate and benthic nitrate fluxes. Global Biogeochem Cycles 19(GB4005). doi:10.1029/2005GB002508

Lutjeharms JRE, Meeuwis JM (1987) The extent and variability of South-East Atlantic upwelling. In: Payne AIL, Gulland JA, Brink KH (eds) The Benguela and comparable ecosystems. S Afr J Mar Sci pp 51-62

Lutjeharms JRE, Stockton PL (1987) Kinematics of the upwelling front off southern Africa. S Afr J Mar Sci 5:35-49

Lutjeharms JRE, Valentine HR (1987) Water types and volumetric considerations of the South-East Atlantic upwelling regime. S Afr J Mar Sci 5:63-71

Marshall J, Kushnir Y, Battisti D, Chang P, Czaya A, Dickson R, Hurrell J, McCartney M, Saravanan R, Visbeck M (2001) North Atlantic climate variability: phenomena, impacts and mechanisms. Int J Climatology 21:1863-1898

Meeuwis JM, Lutjeharms JRE (1990) Surface thermal characteristics of the Angola Benguela Front. S Afr J Mar Sci 9:261-279

Meyer K (1973) Uran-Prospektion vor Südwestafrika. Erzmetall 26(7):313-366

Miller AJ, Schneider N (2000) Interdecadal climate regime dynamics in the North Pacific Ocean: theories, observations and ecosystem impacts. Prog Oceanogr 47:355-379

Mollenhauer G, Eglinton TI, Ohkouchi N, Schneider RR, Müller PJ, Grootes PM, Rullkötter J (2003) Asynchronous alkenone and foraminifera records from the Benguela upwelling system. Geochim Cosmochim Acta 67(12):2157-2171

Montecinos A, Purca S, Pizarro O (2003) Interannual-to-interdecadal sea surface temperature variability along the western coast of South America. Geophys Res Lett 30(11):1570. doi:10.1029/ 2003 GL017345

Müller PJ, Kirst G, Ruhland G, von Storch I, Rosell-Melé A (1998) Calibration of the alkenone paleotemperature index Uk37 based on core-tops from the eastern South Atlantic and the global ocean $\left(60^{\circ} \mathrm{N}-60^{\circ} \mathrm{S}\right)$. Geochim Cosmochim Acta 62(10):1757-1772

Nittrouer CA, DeMaster DJ, McKee BA, Cutshall NH, Larsen IL (1984) The effect of sediment mixing on $\mathrm{Pb}-210$ accumulation rates for the Washington continental shelf. Mar Geol 54(3-4): 201-221

O'Toole M (1980) Seasonal distribution of temperature and salinity in the surface waters off South West Africa, 1972-1974. Sea Fisheries Institute of South Africa, Cape Town

Pichevin L, Martinez P, Bertrand P, Schneider R, Emeis KC (2005) Nitrogen cycling on the Namibian shelf and slope over the last two climatic cycles: local and global forcings. Paleoceanography 20:PA2005, 1-13 
Prahl FG, de Lange GJ, Lyle M, Sparrow MA (1989) Postdepositional stability of long-chain alkenones under contrasting redox conditions. Nature 341:434-437

Prahl FG, Wakeham SG (1987) Calibration of unsaturation patterns in long-chain ketone compositions for palaeotemperature assessment. Nature 330:367-369

Prange M, Schulz M (2004) A coastal upwelling seesaw in the Atlantic Ocean as a result of the closure of the Central American Seaway. Geophys Res Lett 31(L17207):1-4

Schell II (1968) On the relation between the winds off Southwest Africa and the Benguela current and agulhas current penetration in the South Atlantic. Dtsch Hydrographische Z 21(3):109117

Schuette G, Schrader H (1981) Diatoms in surface sediments: a reflection of coastal upwelling. In: Richards FA (ed) Coastal upwelling. American Geophysical Union, Washington, pp 372380

Schwartzlose RA, Alheit J, Bakun A, Baumgartner TR, Cloete R, Crawford RJM, Fletcher WJ, Green-Ruiz Y, Hagen E, Kawasaki T, Lluch-Belda D, Lluch-Cota SE, MacCall AD, Matsuura Y, Nevarez-Martinez MO, Parrish RH, Roy C, Serra R, Shust KV, Ward MN, Zuzunaga JZ (1999) Worldwide large-scale fluctuations of sardine and anchovy populations. S Afr J Mar Sci 21:289-347

Shannon LV, Agenbag JJ, Buys MEL (1987) Large- and mesoscale features of the Angola-Benguela front. S Afr J Mar Sci 5:11-34

Shannon LV, Boyd AJ, Brundrit GB, Taunton-Clark J (1986) On the existence of an El Nino type phenomenon in the Benguela system. J Mar Res 44:495-520

Shannon LV, Nelson G (1996) The Benguela: large-scale features and processes and system variability. In: Wefer G, Berger WH, Siedler G, Webb DJ (eds) The South Atlantic: present and past circulation. Springer, Berlin, pp 163-210

Shannon LV, O'Toole MJ (2003) Sustainability of the Benguela: ex Africa semper aliquid novi. In: Hempel G, Sherman K (eds) Large marine ecosystems of the world: trends in exploitation, protection and research. Elsevier B.V., Amsterdam, pp 227-253

Shannon LV, Pillar SC (1986) The Benguela ecosystem. Part III. Plankton Oceanogr Mar Biol Annu Rev 24:65-170

Stramma L, Peterson RG (1989) Geostrophic transport in the Benguela current region. Phys Oceanogr 19:1440-1448
Struck U, Emeis KC, Alheit J, Schneider RR, Eichner C, Altenbach AV (2002) Changes of the upwelling rates of nitrate preserved in the $\mathrm{d} 15 \mathrm{~N}$-signature of sediments and fish-scales from the diatomaceous mud belt off Namibia. Geobios 35:3-11

Summerhayes CP, Emeis KC, Angel M, Smith RL, Zeitzschel B (eds) (1995a) Upwelling in the ocean: modern processes and ancient records. Dahlem Konferenzen. Wiley, Chichester, p 418

Summerhayes CP, Kroon D, Rosell-Melé A, Jordan RW, Schrader HJ, Hearn R, Villanueva J, Grimalt JO, Eglinton G (1995b) Variability in the Benguela current upwelling system over the past 70,000 years. Prog Oceanogr 35:207-251

Summerhayes CP, Prell WL, Emeis KC (eds) (1992) Upwelling systems: evolution since the early miocene. Geol. Soc. Spec. Publ., 64. Blackwells, London, p 519

Thunell RC, Sigman D, Muller-Karger F, Astor Y, Varela R (2004) Nitrogen isotope dynamics of the Cariaco Basin, Venezuela. Global Biogeochem Cycles 18(GB3001):1-18

Tyrrell T, Lucas MI (2002) Geochemical evidence of denitrification in the Benguela upwellingsystem. Continental Shelf Res 22(17):2497-2511

Vavilova VV (1990) Marine biology: phytoplankton of the Benguela upwelling system off Namibia in the austral autumn of 1985 . Oceanology 30:472-477

Vogt T (2002) Akustische Fazies auf dem Schelf und oberen Kontinentalrand vor Nambia-Auswertung von PARASOUND-Ergebnissen der Reise METEOR 48-2. M.Sc. Thesis, University of Greifswald, Greifswald, p 80

Voß M, Dippner JW, Montoya JP (2001) Nitrogen isotope pattern in the oxygen-deficient waters of the Eastern Tropical North Pacific Ocean. Deep Sea Res I 48:1905-1921

Voß M, Emeis K-C, Hille S, Neumann T, Dippner J (2005) The nitrogen cycle of the Baltic Sea from an isotopic perspective. Global Biogeochem Cycles 19(3):10.1029/2004GB002338

Wasmund N, Lass H-U, Nausch G (2005) Distribution of nutrients, chlorophyll and phytoplankton primary production in relation to hydrographic structures bordering the Benguela-Angolan frontal region. Afr J Mar Sci 27(1):1-15

Watson AJ (1995) Are upwelling areas sources or sinks of $\mathrm{CO}_{2}$ ? In: Summerhayes CP, Emeis K-C, Angel MV, Zeitzschel B (eds) Upwelling in the Ocean: modern processes and ancient records. Wiley, Chichester, pp 321-336 